\title{
LEVEL II SCOUR ANALYSIS FOR BRIDGE 67 (MTHOTH00120067) on TOWN HIGHWAY 12, crossing FREEMAN BROOK, MOUNT HOLLY, VERMONT
}

Open-File Report 98-401

Prepared in cooperation with

VERMONT AGENCY OF TRANSPORTATION

and

FEDERAL HIGHWAY ADMINISTRATION

U.S. Department of the Interior U.S. Geological Survey

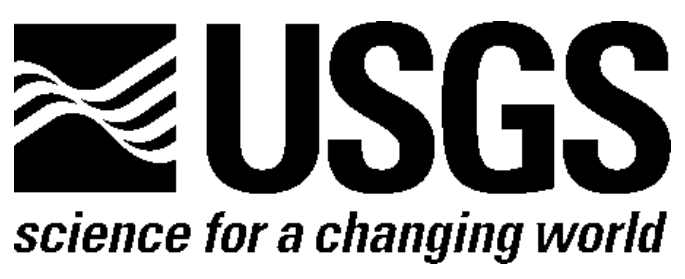




\section{LEVEL II SCOUR ANALYSIS FOR}

BRIDGE 67 (MTHOTH00120067) on

TOWN HIGHWAY 12, crossing

FREEMAN BROOK,

MOUNT HOLLY, VERMONT

By EMILY C. WILD and TIMOTHY SEVERANCE

U.S. Geological Survey

Open-File Report 98-401

Prepared in cooperation with

VERMONT AGENCY OF TRANSPORTATION

and

FEDERAL HIGHWAY ADMINISTRATION 


\title{
U.S. DEPARTMENT OF THE INTERIOR BRUCE BABBITT, Secretary
}

\author{
U.S. GEOLOGICAL SURVEY
}

Thomas J. Casadevall, Acting Director

For additional information write to:

District Chief

U.S. Geological Survey 361 Commerce Way

Pembroke, NH 03275-3718
Copies of this report may be purchased from:

U.S. Geological Survey

Branch of Information Services

Open-File Reports Unit

Box 25286

Denver, CO 80225-0286 


\section{CONTENTS}

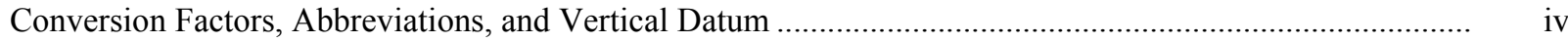

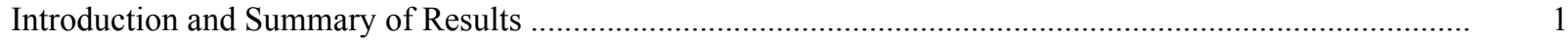

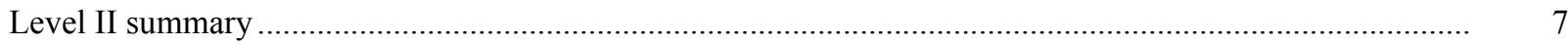

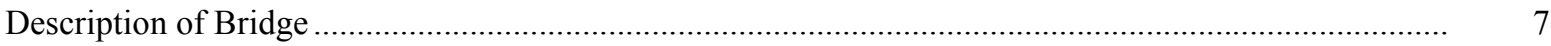

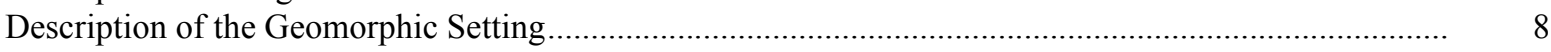

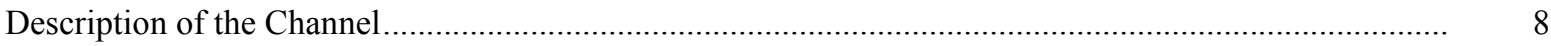

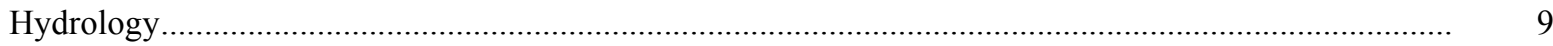

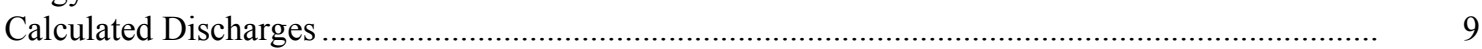

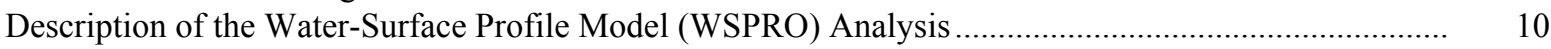

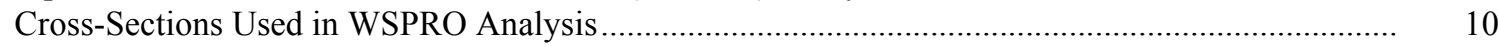

Data and Assumptions Used in WSPRO Model ........................................................................ 11

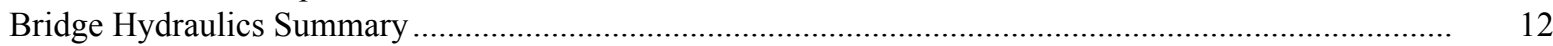

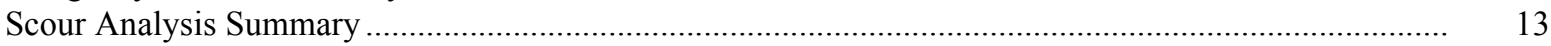

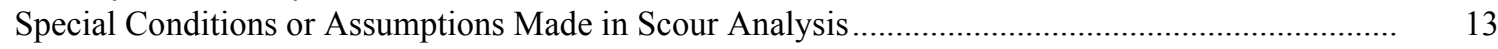

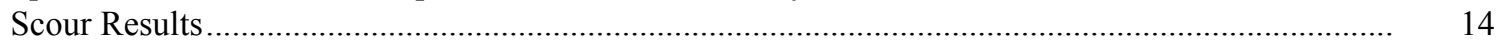

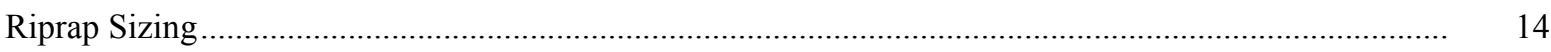

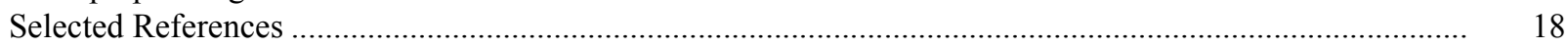

Appendices:

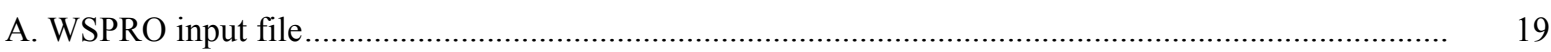

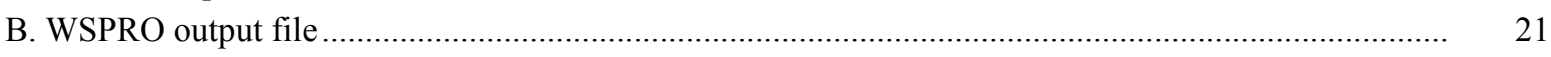

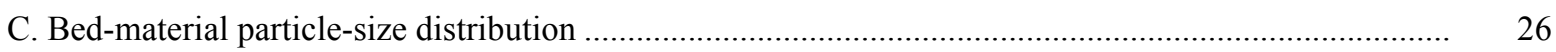

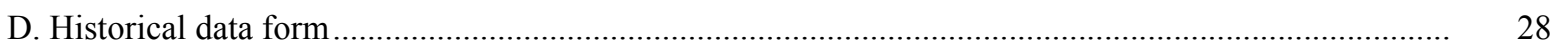

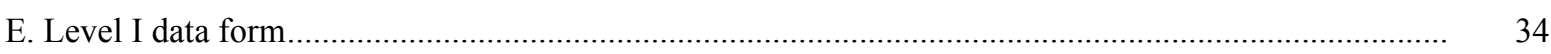

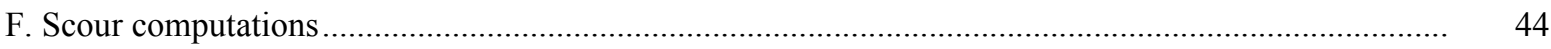

\section{FIGURES}

1. Map showing location of study area on two USGS 1:24,000 scale maps

2. Map showing location of study area on Vermont Agency of Transportation town highway map

3. Structure MTHOTH00120067 viewed from upstream (October 5, 1995)

4

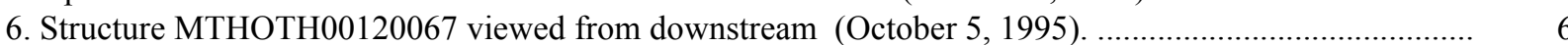

7. Water-surface profiles for the 100- and 500-year discharges at structure

MTHOTH00120067 on Town Highway 12, crossing Freeman Brook,

Mount Holly, Vermont.

8. Scour elevations for the 100- and 500-year discharges at structure

MTHOTH00120067 on Town Highway 12, crossing Freeman Brook,

Mount Holly, Vermont.

\section{TABLES}

1. Remaining footing/pile depth at abutments for the 100-year discharge at structure

MTHOTH00120067 on Town Highway 12, crossing Freeman Brook,

Mount Holly, Vermont.

2. Remaining footing/pile depth at abutments for the 500-year discharge at structure

MTHOTH00120067 on Town Highway 12, crossing Freeman Brook,

Mount Holly, Vermont. 


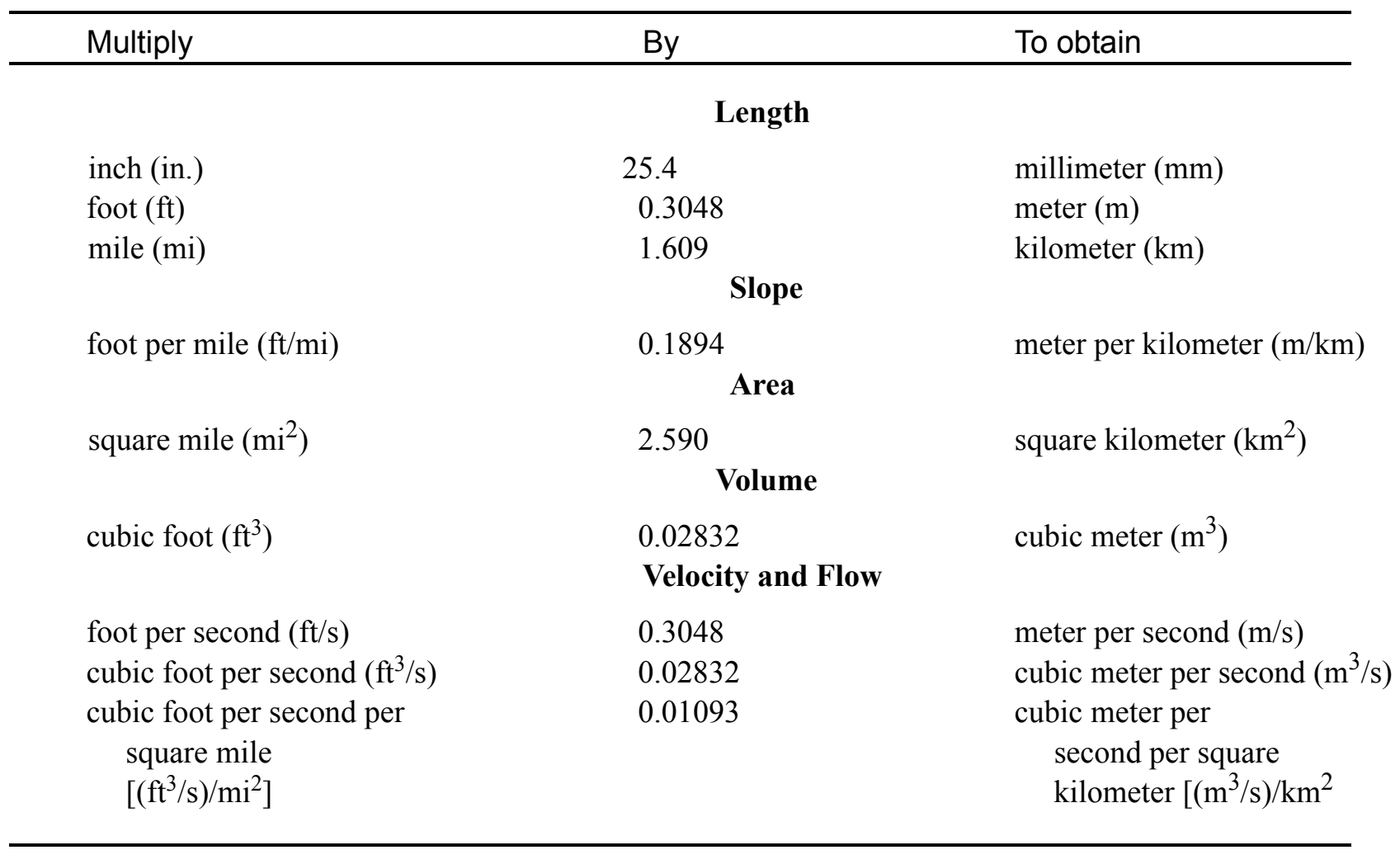

\section{OTHER ABBREVIATIONS}

$\begin{array}{lrlr}\mathrm{BF} & \text { bank full } & \text { LWW } & \text { left wingwall } \\ \mathrm{cfs} & \text { cubic feet per second } & \text { Max } & \text { maximum } \\ \mathrm{D}_{50} & \text { median diameter of bed material } & \text { MC } & \text { main channel } \\ \mathrm{DS} & \text { downstream } & \text { RAB } & \text { right abutment } \\ \mathrm{elev} & \text { elevation } & \text { RABUT } & \text { face of right abutment } \\ \mathrm{f} / \mathrm{p} & \text { flood plain } & \text { RB } & \text { right bank } \\ \mathrm{ft} & \text { square feet } & \text { ROB } & \text { right overbank } \\ \mathrm{ft} / \mathrm{ft} & \text { feet per foot } & \text { RWW } & \text { right wingwall } \\ \mathrm{FEMA} & \text { Federal Emergency Management Agency } & \text { TH } & \text { town highway } \\ \mathrm{FHWA} & \text { Federal Highway Administration } & \text { UB } & \text { under bridge } \\ \mathrm{JCT} & \text { junction } & \text { US } & \text { upstream } \\ \text { LAB } & \text { left abutment } & \text { USGS } & \text { United States Geological Survey } \\ \text { LABUT } & \text { face of left abutment } & \text { VTAOT } & \text { Vermont Agency of Transportation } \\ \text { LB } & \text { left bank } & \text { WSPRO } & \text { water-surface profile model } \\ \text { LOB } & \text { left overbank } & \text { yr } & \text { year }\end{array}$

In this report, the words "right" and "left" refer to directions that would be reported by an observer facing downstream. Sea level: In this report, "sea level" refers to the National Geodetic Vertical Datum of 1929-- a geodetic datum derived from a general adjustment of the first-order level nets of the United States and Canada, formerly called Sea Level Datum of 1929.

In the appendices, the above abbreviations may be combined. For example, USLB would represent upstream left bank. 


\title{
LEVEL II SCOUR ANALYSIS FOR BRIDGE 67 (MTHOTH00120067) ON TOWN HIGHWAY 12, CROSSING FREEMAN BROOK, MOUNT HOLLY, VERMONT
}

\author{
By Emily C. Wild and Timothy Severance
}

\section{INTRODUCTION AND SUMMARY OF RESULTS}

This report provides the results of a detailed Level II analysis of scour potential at structure MTHOTH00120067 on Town Highway 12 crossing Freeman Brook, Mount Holly, Vermont (figures 1-8). A Level II study is a basic engineering analysis of the site, including a quantitative analysis of stream stability and scour (FHWA, 1993). Results of a Level I scour investigation also are included in appendix $\mathrm{E}$ of this report. A Level I investigation provides a qualitative geomorphic characterization of the study site. Information on the bridge, gleaned from Vermont Agency of Transportation (VTAOT) files, was compiled prior to conducting Level I and Level II analyses and is found in appendix D.

The site is in the Green Mountain section of the New England physiographic province in south-central Vermont. The $11.4-\mathrm{mi}^{2}$ drainage area is in a predominantly rural and forested basin. In the vicinity of the study site, the surface cover is forested.

In the study area, Freeman Brook has an incised, sinuous channel with a slope of approximately $0.01 \mathrm{ft} / \mathrm{ft}$, an average channel top width of $51 \mathrm{ft}$ and an average bank height of $6 \mathrm{ft}$. The channel bed material ranges from sand to boulders with a median grain size $\left(\mathrm{D}_{50}\right)$ of $55.7 \mathrm{~mm}(0.183 \mathrm{ft})$. The geomorphic assessment at the time of the Level I and Level II site visit on October 5, 1995, indicated that the reach was stable.

The Town Highway 12 crossing of Freeman Brook is a 34-ft-long, two-lane bridge consisting of a 30-foot prestressed concrete-slab span (Vermont Agency of Transportation, written communication, March 15, 1995). The opening length of the structure parallel to the bridge face is $29.5 \mathrm{ft}$. The bridge is supported by vertical, concrete abutments with wingwalls. The channel is skewed approximately 50 degrees to the opening while the opening-skew-to-roadway is 15 degrees. 
Along the upstream right wingwall, the right abutment and the downstream right wingwall, a scour hole approximately 1.0 to $2.0 \mathrm{ft}$ deeper than the mean thalweg depth was observed during the Level I assessment. Scour protection measures at the site included type-1 stone fill (less than 12 inches diameter) along the downstream end of the downstream right wingwall; type- 2 stone fill (less than 36 inches diameter) along the upstream left wingwall, the left abutment, the downstream left wingwall and the upstream left and right banks; type3 stone fill (less than 48 inches diameter) along the downstream left and right banks; and type-4 stone fill (less than 60 inches diameter) along the upstream right wingwall. Additional details describing conditions at the site are included in the Level II Summary and appendices $\mathrm{D}$ and $\mathrm{E}$.

Scour depths and recommended rock rip-rap sizes were computed using the general guidelines described in Hydraulic Engineering Circular 18 (Richardson and Davis, 1995) for the 100- and 500-year discharges. Total scour at a highway crossing is comprised of three components: 1) long-term streambed degradation; 2) contraction scour (due to accelerated flow caused by a reduction in flow area at a bridge) and; 3 ) local scour (caused by accelerated flow around piers and abutments). Total scour is the sum of the three components. Equations are available to compute depths for contraction and local scour and a summary of the results of these computations follows.

Contraction scour for all modelled flows ranged from 2.6 to $3.9 \mathrm{ft}$. The worst-case contraction scour occurred at the 500-year discharge. Left abutment scour ranged from 7.9 to $10.0 \mathrm{ft}$. Right abutment scour ranged from 12.7 to $15.2 \mathrm{ft}$. The worst-case abutment scour occurred at the 500-year discharge. Additional information on scour depths and depths to armoring are included in the section titled "Scour Results". Scoured-streambed elevations, based on the calculated scour depths, are presented in tables 1 and 2. A cross-section of the scour computed at the bridge is presented in figure 8. Scour depths were calculated assuming an infinite depth of erosive material and a homogeneous particle-size distribution.

It is generally accepted that the Froehlich equation (abutment scour) gives "excessively conservative estimates of scour depths" (Richardson and Davis, 1995, p. 46). Usually, computed scour depths are evaluated in combination with other information including (but not limited to) historical performance during flood events, the geomorphic stability assessment, existing scour protection measures, and the results of the hydraulic analyses. Therefore, scour depths adopted by VTAOT may differ from the computed values documented herein. 


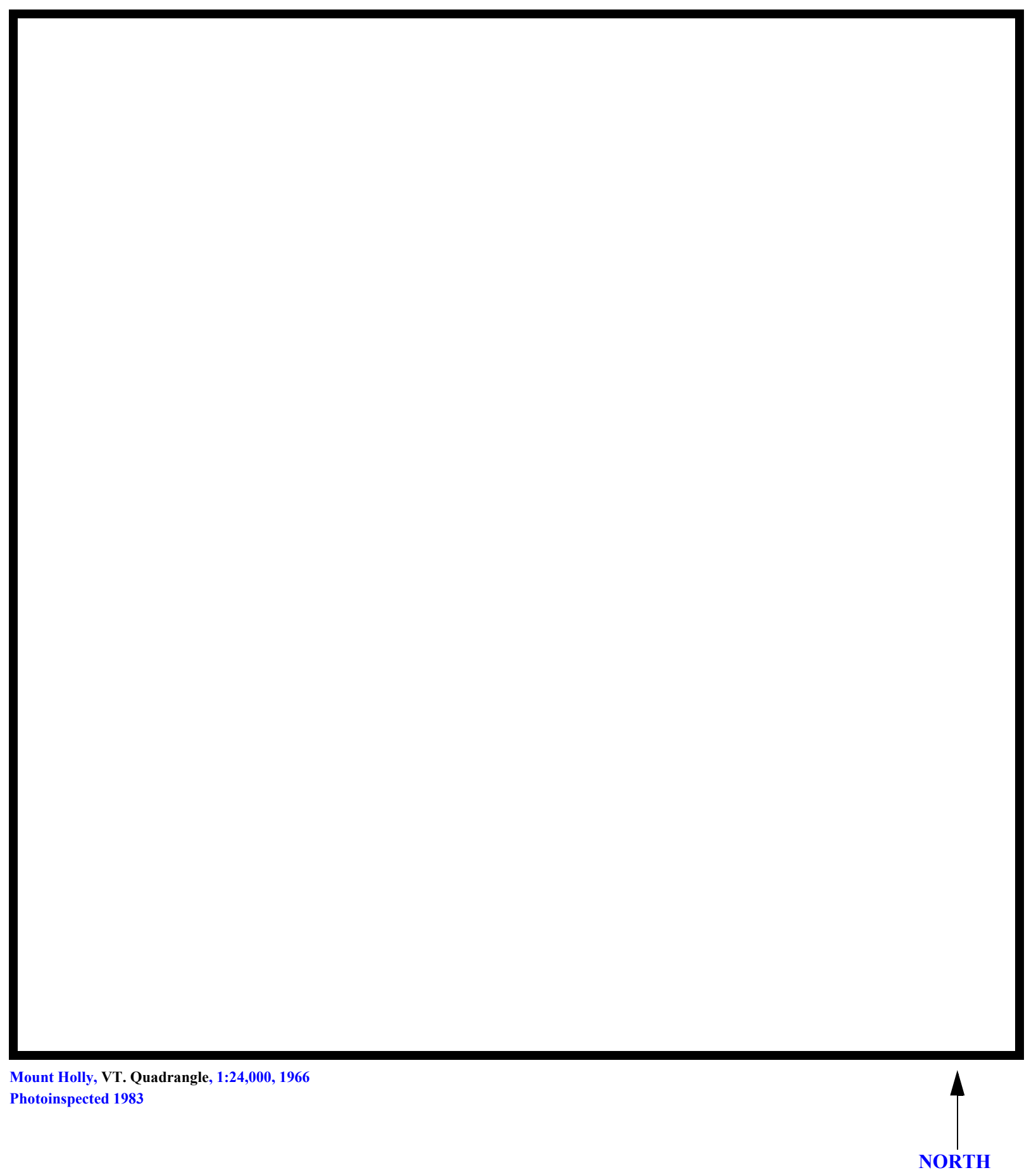

Figure 1. Location of study area on USGS 1:24,000 scale map. 
Figure 2. Location of study area on Vermont Agency of Transportation town highway map. 

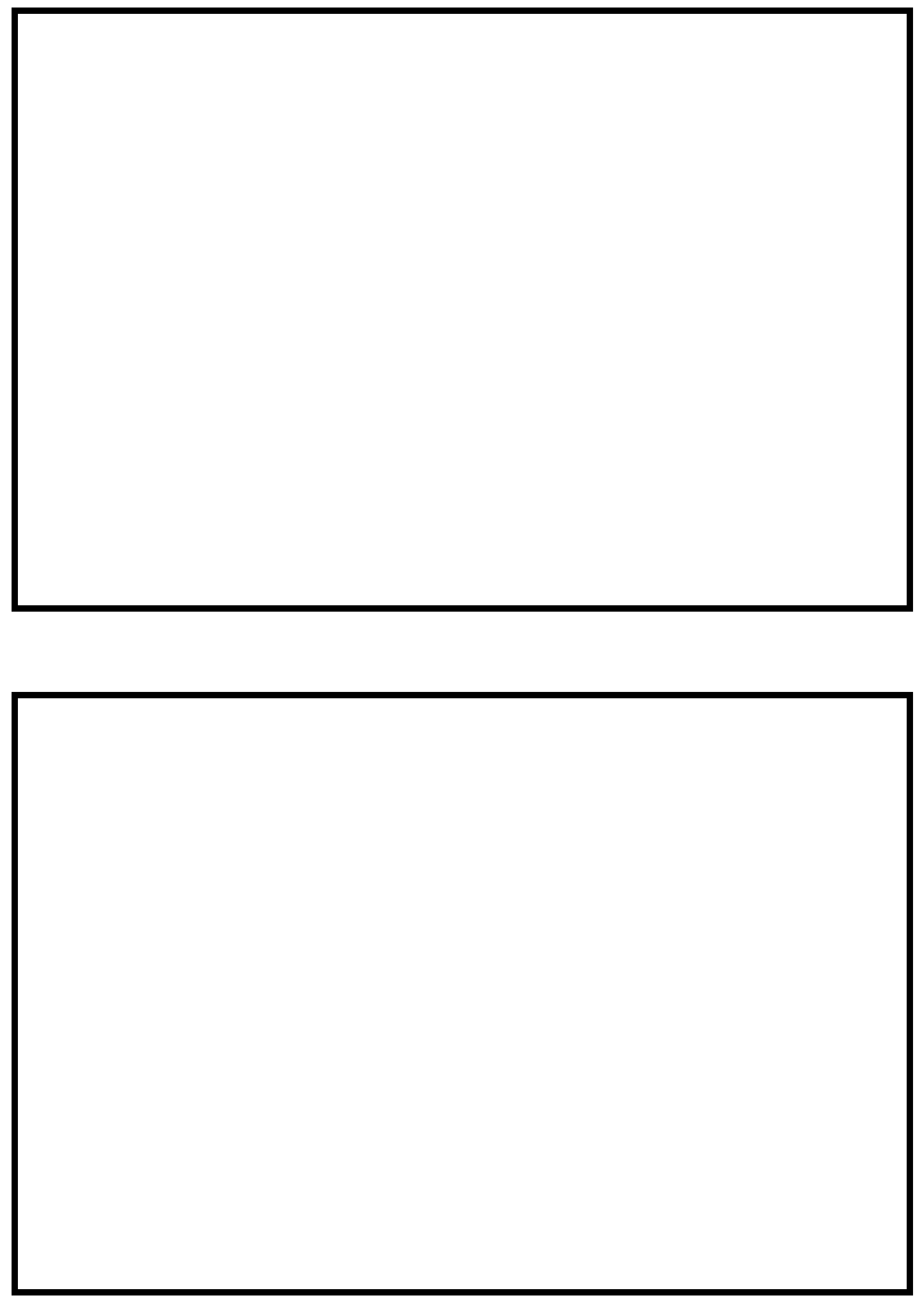

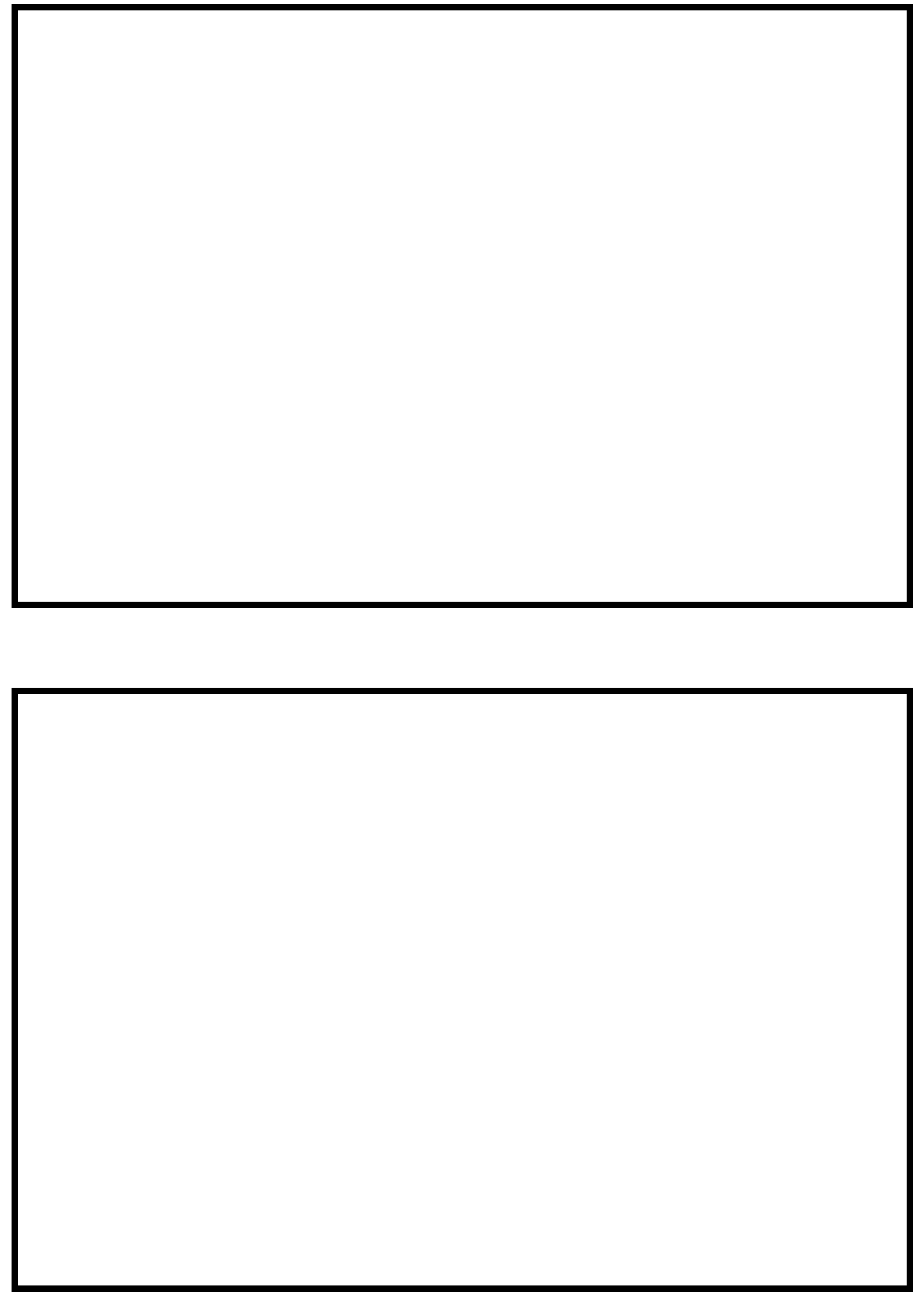


\section{LEVEL II SUMMARY}

\begin{tabular}{llllll} 
Structure Number & MTHOTH00120067 & Stream & \multicolumn{3}{c}{ Freeman Brook } \\
& Roud & TH 12 & District & Road
\end{tabular}

\section{Description of Bridge}

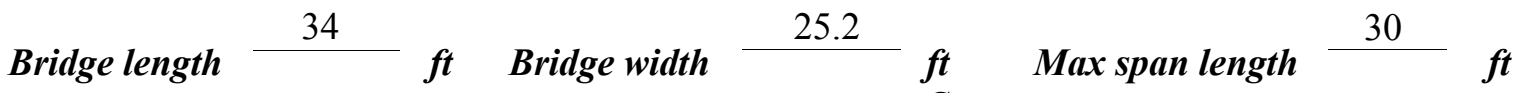
Alignment of bridge to road (on curve or straight)

Abutment type Vertical, concrete

Stone fill on abutment?

$$
\text { Yes }
$$

\section{Embankment type} Curve

Drmanimsin.. af ota... sill Type-1, along the downstream end of the downstream right wingwall. Type-2, along the upstream left wingwall, left abutment and downstream left wingwall. Type-4 along the upstream right wingwall.

Abutments and wingwalls are concrete. There is a 1.1

foot deep scour hole in front of the right abutment, and the right abutment footing is exposed. Yes

$$
50 \quad \text { Yes }
$$

Angle

Is bridge skewed to flood flow according to There ' survey?

is a moderate channel bend through the bridge. The sçour hole has developed in the location where the flow impacts the right abutment.

Debris accumulation on bridge at time of Level I or Level II site visit:

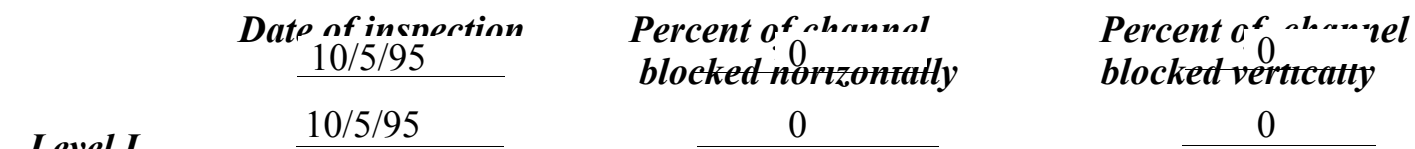

Level II

Moderate. There is some debris in the upstream reach.

\section{Potential for debris}

None, 10/5/95.

Doscriho anv fonturos noar ar at tho hridoo that mav affort flow, (includo ahsorvation dato) 


\section{Description of the Geomorphic Setting}

General topography The channel is located within a high relief valley.

Geomorphic conditions at bridge site: downstream (DS), upstream (US)

Date of inspection $\quad 10 / 5 / 95$

DS left: $\quad$ There is a steep channel bank and a narrow flood plain.

DS right: The channel bank and overbank are moderately sloped (road embankment).

US left: $\quad$ There is a steep channel bank and a narrow flood plain.

US right: $\quad$ The channel bank and overbank are moderately sloped.

\section{Description of the Channel}

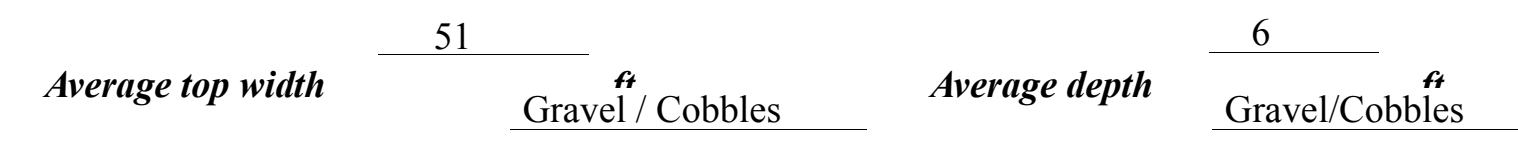

Predominant bed material

Bank material Sinuous but stable

with non-alluvial channel boundaries and a narrow flood plain.

$10 / 5 / 95$

Vegetative ${ }^{1}$ Trees, brush and shrub

DS left: $\quad$ Trees and brush and Town Highway 12

DS right: $\quad$ Trees, shrub, brush and Town Highway 12

US left: $\quad$ Trees, brush and grass

US right: $\quad$ Yes

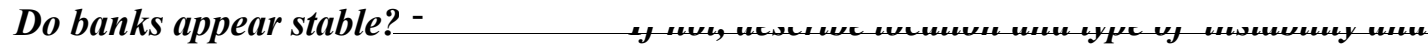

date of observatton.

None, 10/5/95.

Describe any obstructions in channel and date of observation. 


\title{
Hydrology
}

Drainage area $\frac{11.4}{m_{i}{ }^{2}}$

Percentage of drainage area in physiographic provinces: (approximate)

Physiographic province/section

New England/Green Mountain
Percent of drainage area 100

\begin{abstract}
Is drainage area considered rural or urban?
Rural None.

urbanization:-

Describe any significant
\end{abstract}

Is there a USGS gage on the stream of interest?

No

USGS gage description

USGS gage number

Gage drainage area $\mathrm{mi}^{2}$

$--$

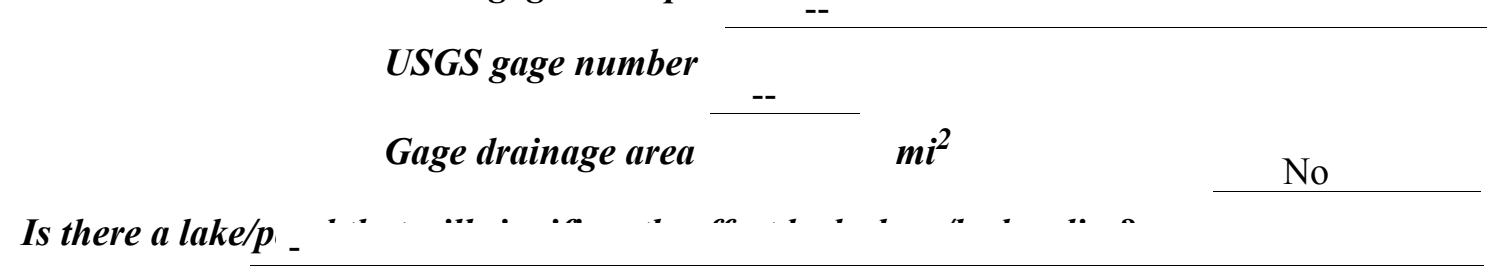

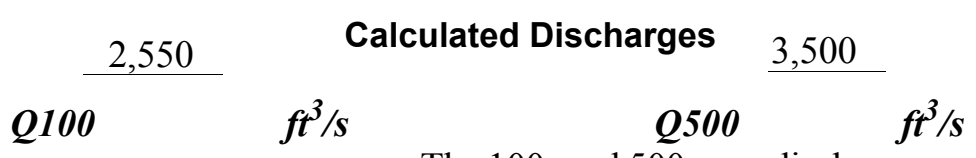

The 100- and 500-year discharges are based on flood

frequency estimates available from the VTAOT database (Vermont Agency of Transportation, written communication, May 1995). These values were selected due to the central tendency of the discharge frequency curve with others which were developed from empirical relationships (Benson, 1962; Johnson and Tasker, 1974; FHWA, 1983; Potter, 1957a\&b; Talbot, 1887). Each curve was extended graphically to the 500 -year discharge. 


\section{Description of the Water-Surface Profile Model (WSPRO) Analysis}

Datum for WSPRO analysis (USGS survey, sea level, VTAOT plans) ～USGS survey

Datum tie between USGS survey and VTAOT plans To obtain VTAOT datum, add

$21.3 \mathrm{ft}$ to USGS arbitrary survey datum.

Description of reference marks used to determine USGS datum. $\quad$ RM1 is a chiseled X on top of the upstream end of the right abutment (elev. $498.73 \mathrm{ft}$, arbitrary survey datum). RM2 is a chiseled X on top of the upstream end of the upstream left wingwall (elev. $492.91 \mathrm{ft}$, arbitrary

survey datum). RM3 is a chiseled X on top of the downstream end of the left abutment (elev.

$499.83 \mathrm{ft}$, arbitrary survey datum).

\section{Cross-Sections Used in WSPRO Analysis}

\begin{tabular}{cccl}
\hline${ }^{1}$ Cross-section & $\begin{array}{c}\text { Section } \\
\text { Reference } \\
\text { Distance } \\
\text { (SRD) } \text { in feet }\end{array}$ & $\begin{array}{c}{ }^{2} \text { Cross-section } \\
\text { development }\end{array}$ & \multicolumn{1}{c}{ Comments } \\
\hline EXIT1 & -46 & 1 & Exit section \\
FULLV & 0 & 2 & $\begin{array}{l}\text { Downstream Full-valley } \\
\text { section (Templated from } \\
\text { EXITX) }\end{array}$ \\
BRIDG & 0 & 1 & Bridge section \\
RDWAY & 15 & 1 & Road Grade section \\
APPR3 & 59 & 1 & Approach section \\
\hline
\end{tabular}

${ }^{1}$ For location of cross-sections see plan-view sketch included with Level I field form, Appendix E. For more detail on how cross-sections were developed see WSPRO input file. 


\section{Data and Assumptions Used in WSPRO Model}

Hydraulic analyses of the reach were done by use of the Federal Highway Administration's WSPRO step-backwater computer program (Shearman and others, 1986, and Shearman, 1990). The analyses reported herein reflect conditions existing at the site at the time of the study. Furthermore, in the development of the model it was necessary to assume no accumulation of debris or ice at the site. Results of the hydraulic model are presented in the Bridge Hydraulic Summary, appendix B, and figure 7.

Channel roughness factors (Manning's " $n$ ") used in the hydraulic model were estimated using field inspections at each cross section following the general guidelines described by Arcement and Schneider (1989). Final adjustments to the values were made during the modelling of the reach. Channel " $n$ " values for the reach ranged from 0.045 to 0.055 , and overbank " $n$ " values ranged from 0.060 to 0.070 .

Normal depth at the exit section (EXIT1) was assumed as the starting water surface. This depth was computed by use of the slope-conveyance method outlined in the user's manual for WSPRO (Shearman, 1990). The slope used was $0.0104 \mathrm{ft} / \mathrm{ft}$, which was calculated from thalweg points surveyed downstream of the bridge.

The modelled approach section (APPR3) was surveyed one bridge length upstream of the upstream face, as recommended by Shearman and others (1986). This location provides a consistent method for determining scour variables.

For the 100-year and 500-year discharges, WSPRO assumes critical depth at the bridge

section. Supercritical models were developed for these discharges. After analyzing the supercritical and subcritical profiles for each discharge, it was determined that the water surface profile does pass through critical depth within the bridge opening. Thus, the assumptions of critical depth at the bridge are satisfactory solutions. 


\section{Bridge Hydraulics Summary}

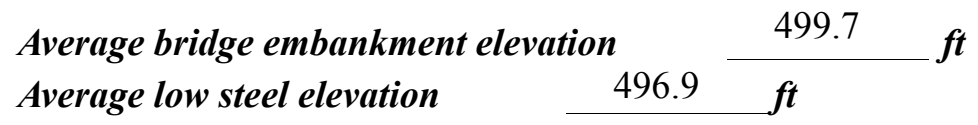

100-year discharge $\quad 2,550 \quad \mathrm{ft}^{3} / \mathrm{s}$

Water-surface elevation in bridge opening $\quad 489.6 \quad f t$

Road overtopping? ___ No Discharge over road ___ -- $\mathrm{ft}^{3} / \mathrm{s}$

Area of flow in bridge opening $\quad 179 \quad \mathrm{ft}^{2}$

Average velocity in bridge opening $14.2 \mathrm{ft} / \mathrm{s}$

Maximum WSPRO tube velocity at bridge $18.5 \mathrm{ft} / \mathrm{s}$

Water-surface elevation at Approach section with bridge 493.3

Water-surface elevation at Approach section without bridge $\quad 490.5$

Amount of backwater caused by bridge $\quad 2.8$ it

500-year discharge $\quad 3,500 \quad \mathrm{ft}^{3} / \mathrm{s}$

Water-surface elevation in bridge opening $\quad 491.1 \mathrm{ft}$

Road overtopping? ___ No Discharge over road ___ -- $\mathrm{ft}^{3} / \mathrm{s}$

Area of flow in bridge opening $\quad 221 \quad \boldsymbol{f t}^{2}$

Average velocity in bridge opening $15.8 \mathrm{ft} / \mathrm{s}$

Maximum WSPRO tube velocity at bridge 20.8 's

Water-surface elevation at Approach section with bridge 495.6

Water-surface elevation at Approach section without bridge $\quad 491.6$

Amount of backwater caused by bridge $4.0, t$

Incipient overtopping discharge ___ -- $\mathrm{ft}^{3} / \mathrm{s}$

Water-surface elevation in bridge opening $\quad--\quad t$

Area of flow in bridge opening _ -- $\mathrm{ft}^{2}$

Average velocity in bridge opening __- $\quad \mathrm{ft} / \mathrm{s}$

Maximum WSPRO tube velocity at bridge _ -- $\mathrm{ft} / \mathrm{s}$

Water-surface elevation at Approach section with bridge

Water-surface elevation at Approach section without bridge

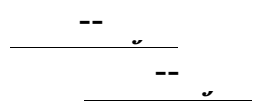

Amount of backwater caused by bridge _ 


\section{Scour Analysis Summary}

\section{Special Conditions or Assumptions Made in Scour Analysis}

Scour depths were computed using the general guidelines described in Hydraulic Engineering Circular 18 (Richardson and Davis, 1995). Scour depths were calculated assuming an infinite depth of erosive material and a homogeneous particle-size distribution. The results of the scour analyses for the 100- and 500-year discharges are presented in tables 1 and 2 and the scour depths are shown graphically in figure 8. Bottom of footing elevations shown in figure 8 were taken from the bridge construction plans available from the VTAOT.

Contraction scour for the 100-year and 500-year discharges was computed by use of the Laursen clear-water contraction scour equation (Richardson and Davis, 1995, p. 32, equation 20). Variables for the Laursen clear-water contraction scour equation include the discharge through the bridge, the width of the channel at the bridge, and the median grain size of the channel bed material.

Abutment scour was computed by use of the Froehlich equation (Richardson and Davis, 1995, p. 48, equation 28). Variables for the Froehlich equation include the Froude number of the flow approaching the embankments, the length of the embankment blocking flow, and the depth of flow approaching the embankment less any roadway overtopping. 


\section{Scour Results}

Contraction scour:

Main channel

Live-bed scour

Clear-water scour

Depth to armoring

Left overbank

Right overbank

Local scour:

Abutment scour

Left abutment

Right abutment

Pier scour

Pier 1

Pier 2

Pier 3
7.9

$12.7-$
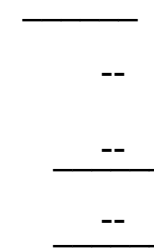

Incipient

500-year overtopping discharge discharge

(Scour depths in feet)
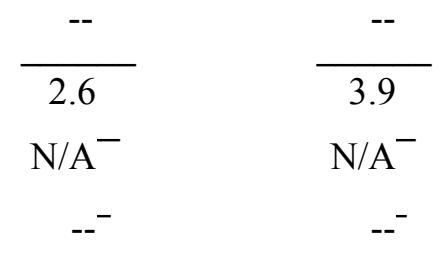

N/A

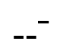

$--$
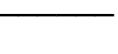

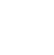

Riprap Sizing

Abutments:

Left abutment

Right abutment

Piers:

Pier 1

Pier 2
10.0

15.2-
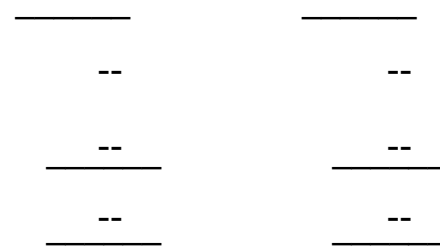

$--$

--

-- 


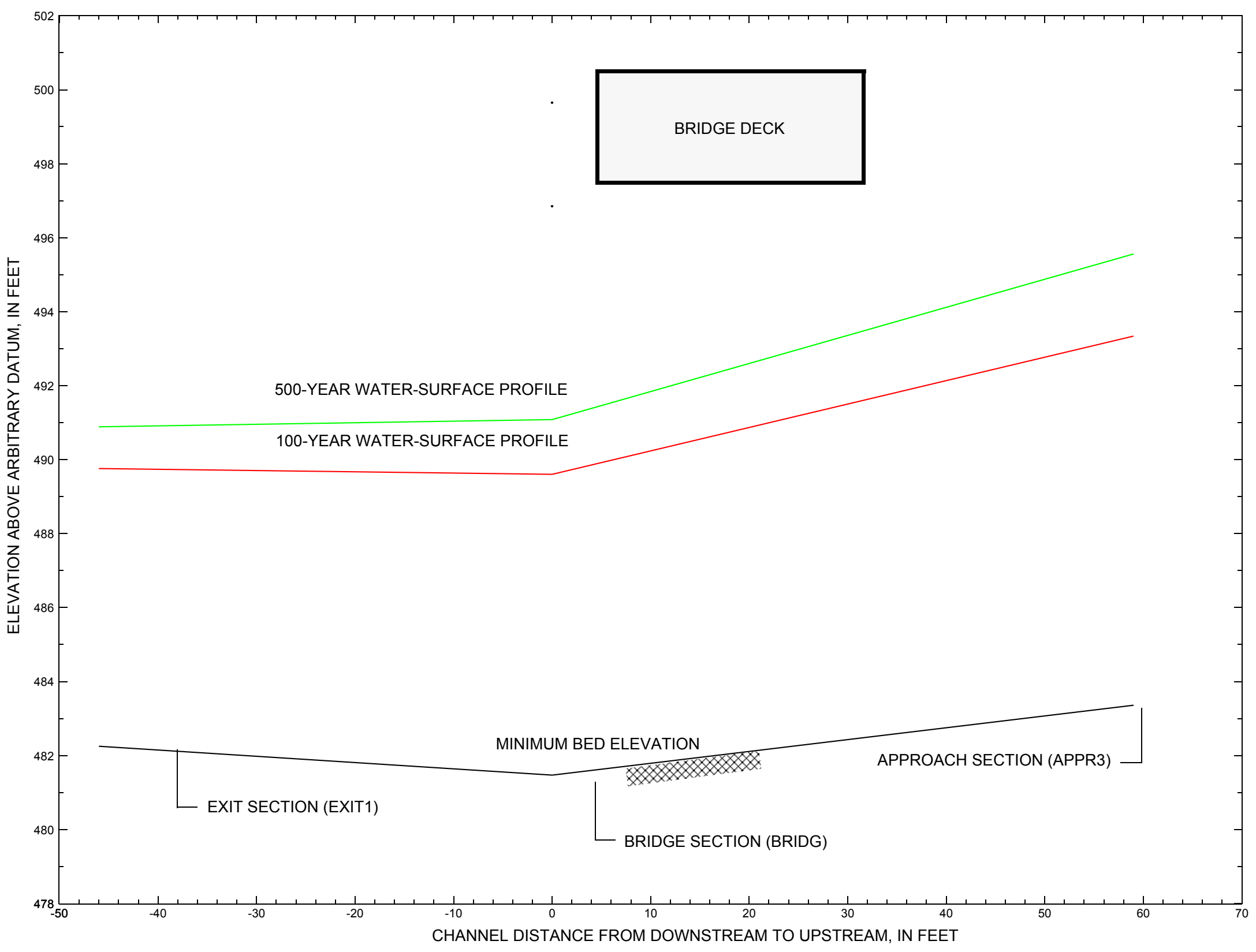

Figure 7. Water-surface profiles for the 100- and 500-year discharges at structure MTHOTH00120067 on Town Highway 12 , crossing Freeman Brook, Mount Holly, Vermont. 


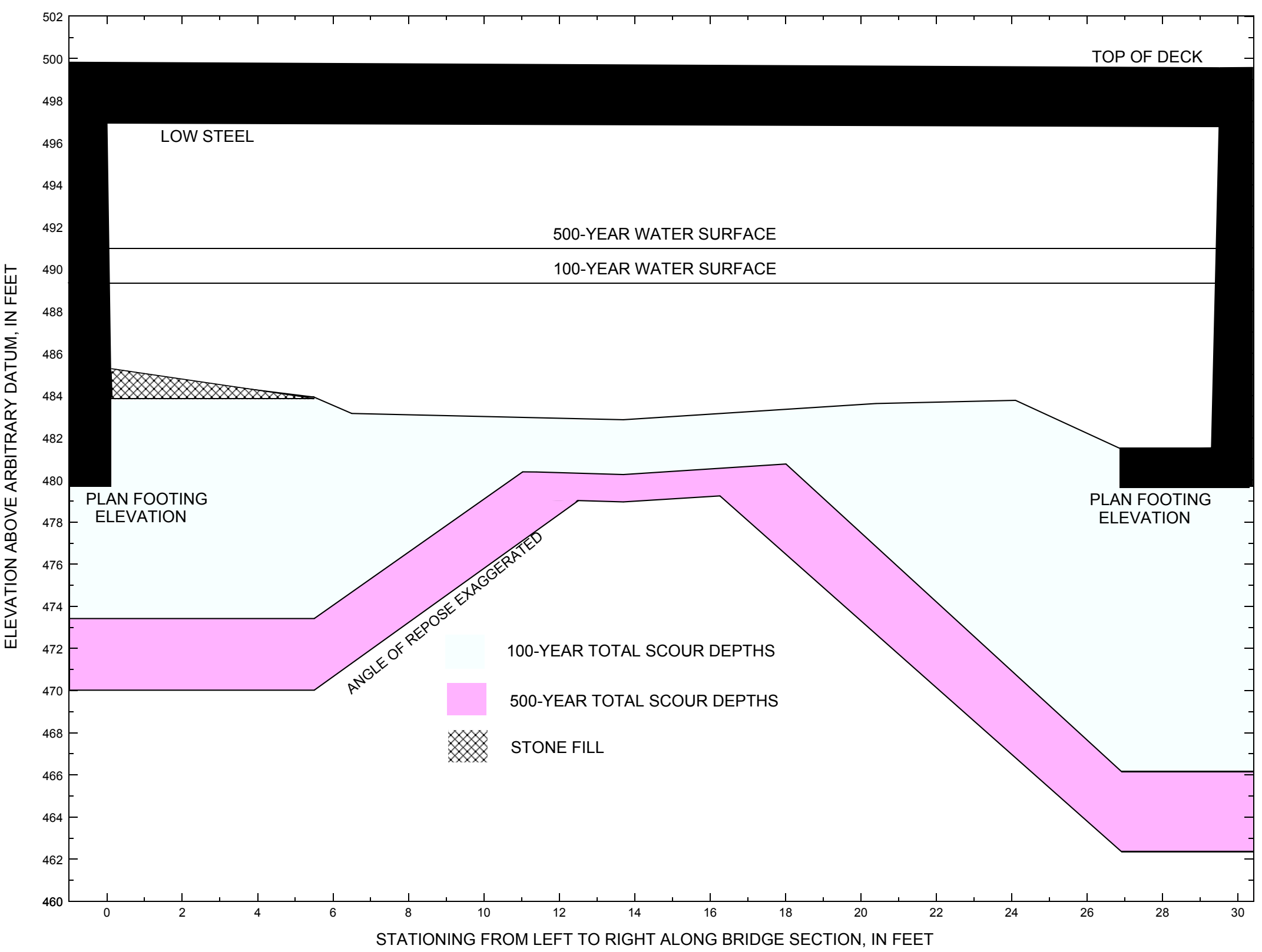

Figure 8. Scour elevations for the 100- and 500-year discharges at structure MTHOTH00120067 on Town Highway 12, crossing Freeman Brook, Mount Holly, Vermont. 
Table 1. Remaining footing/pile depth at abutments for the 100-year discharge at structure MTHOTH00120067 on Town Highway 12, crossing Freeman Brook, Mount Holly, Vermont.

[VTAOT, Vermont Agency of Transportation; --, no data]

\begin{tabular}{|c|c|c|c|c|c|c|c|c|c|c|c|}
\hline Description & Station $^{1}$ & $\begin{array}{l}\text { VTAOT } \\
\text { minimum } \\
\text { low-chord } \\
\text { elevation } \\
\text { (feet) }\end{array}$ & $\begin{array}{l}\text { Surveyed } \\
\text { minimum } \\
\text { low-chord } \\
\text { elevation } \\
\quad \text { (feet) }\end{array}$ & $\begin{array}{c}\text { Bottom of } \\
\text { footing/pile } \\
\text { elevation }^{2} \\
\text { (feet) }\end{array}$ & $\begin{array}{c}\text { Channel } \\
\text { elevation at } \\
\text { abutment/ } \\
\text { pier }^{2} \\
\text { (feet) }\end{array}$ & $\begin{array}{l}\text { Contraction } \\
\text { scour depth } \\
\text { (feet) }\end{array}$ & $\begin{array}{l}\text { Abutment } \\
\text { scour } \\
\text { depth } \\
\text { (feet) }\end{array}$ & $\begin{array}{l}\text { Pier } \\
\text { scour } \\
\text { depth } \\
\text { (feet) }\end{array}$ & $\begin{array}{l}\text { Depth of } \\
\text { total scour } \\
\text { (feet) }\end{array}$ & $\begin{array}{c}\text { Elevation of } \\
\text { scour }^{2} \\
\text { (feet) }\end{array}$ & $\begin{array}{l}\text { Remaining } \\
\text { footing/pile } \\
\text { depth } \\
\text { (feet) }\end{array}$ \\
\hline \multicolumn{12}{|c|}{100 -year discharge is 2,550 cubic-feet per second } \\
\hline Left abutment & 0.0 & 497.0 & 496.9 & 479.7 & 483.9 & 2.6 & 7.9 & -- & 10.5 & 473.4 & -6.3 \\
\hline Right abutment & 29.5 & 496.7 & 496.8 & 479.7 & 481.5 & 2.6 & 12.7 & -- & 15.3 & 466.2 & -13.5 \\
\hline
\end{tabular}

1.Measured along the face of the most constricting side of the bridge.

2.Arbitrary datum for this study.

Table 2. Remaining footing/pile depth at abutments for the 500-year discharge at structure MTHOTH00120067 on Town Highway 12, crossing Freeman Brook, Mount Holly, Vermont.

[VTAOT, Vermont Agency of Transportation; --, no data]

\begin{tabular}{|c|c|c|c|c|c|c|c|c|c|c|c|}
\hline Description & Station $^{1}$ & $\begin{array}{l}\text { VTAOT } \\
\text { minimum } \\
\text { low-chord } \\
\text { elevation } \\
\text { (feet) }\end{array}$ & $\begin{array}{l}\text { Surveyed } \\
\text { minimum } \\
\text { low-chord } \\
\text { elevation } \\
\text { (feet) }\end{array}$ & $\begin{array}{c}\text { Bottom of } \\
\text { footing/pile } \\
\text { elevation } \\
\text { (feet) }\end{array}$ & $\begin{array}{c}\text { Channel } \\
\text { elevation at } \\
\text { abutment/ } \\
\text { pier }^{2} \\
\text { (feet) }\end{array}$ & $\begin{array}{l}\text { Contraction } \\
\text { scour depth } \\
\text { (feet) }\end{array}$ & $\begin{array}{l}\text { Abutment } \\
\text { scour } \\
\text { depth } \\
\text { (feet) }\end{array}$ & $\begin{array}{l}\text { Pier } \\
\text { scour } \\
\text { depth } \\
\text { (feet) }\end{array}$ & $\begin{array}{l}\text { Depth of } \\
\text { total scour } \\
\text { (feet) }\end{array}$ & $\begin{array}{c}\text { Elevation of } \\
\text { scour }^{2} \\
\text { (feet) }\end{array}$ & $\begin{array}{c}\text { Remaining } \\
\text { footing/pile } \\
\text { depth } \\
\text { (feet) }\end{array}$ \\
\hline \multicolumn{12}{|c|}{500 -year discharge is 3,500 cubic-feet per second } \\
\hline Left abutment & 0.0 & 497.0 & 496.9 & 479.7 & 483.9 & 3.9 & 10.0 & -- & 13.9 & 470.0 & -9.7 \\
\hline Right abutment & 29.5 & 496.7 & 496.8 & 479.7 & 481.5 & 3.9 & 15.2 & -- & 19.1 & 462.4 & -17.3 \\
\hline
\end{tabular}

1.Measured along the face of the most constricting side of the bridge.

2.Arbitrary datum for this study. 


\section{SELECTED REFERENCES}

Arcement, G.J., Jr., and Schneider, V.R., 1989, Guide for selecting Manning's roughness coefficients for natural channels and flood plains: U.S. Geological Survey Water-Supply Paper 2339, 38 p.

Barnes, H.H., Jr., 1967, Roughness characteristics of natural channels: U.S. Geological Survey Water-Supply Paper 1849,213 p.

Benson, M. A., 1962, Factors Influencing the Occurrence of Floods in a Humid Region of Diverse Terrain: U.S. Geological Survey WaterSupply Paper 1580-B, 64 p.

Brown, S.A. and Clyde, E.S., 1989, Design of riprap revetment: Federal Highway Administration Hydraulic Engineering Circular No. 11, Publication FHWA-IP-89-016, 156 p.

Federal Highway Administration, 1983, Runoff estimates for small watersheds and development of sound design: Federal Highway Administration Report FHWA-RD-77-158.

Federal Highway Administration, 1993, Stream Stability and Scour at Highway Bridges: Participant Workbook: Federal Highway Administration Report FHWA-HI-91-011.

Froehlich, D.C., 1989, Local scour at bridge abutments in Ports, M.A., ed., Hydraulic Engineering--Proceedings of the 1989 National Conference on Hydraulic Engineering: New York, American Society of Civil Engineers, p. 13-18.

Hayes, D.C.,1993, Site selection and collection of bridge-scour data in Delaware, Maryland, and Virginia: U.S. Geological Survey WaterResources Investigation Report 93-4017, 23 p.

Interagency Advisory Committee on Water Data, 1982, Guidelines for determining flood flow frequency: U.S. Geological Survey, Bulletin 17B of the Hydrology Subcommittee, 190 p.

Johnson, C.G. and Tasker, G.D.,1974, Progress report on flood magnitude and frequency of Vermont streams: U.S. Geological Survey OpenFile Report 74-130, 37 p.

Lagasse, P.F., Schall, J.D., Johnson, F., Richardson, E.V., Chang, F., 1995, Stream Stability at Highway Structures: Federal Highway Administration Hydraulic Engineering Circular No. 20, Publication FHWA-IP-90-014, 144 p.

Laursen, E.M., 1960, Scour at bridge crossings: Journal of the Hydraulics Division, American Society of Civil Engineers, v. 86, no. HY2, p. 39-53.

Potter, W. D., 1957a, Peak rates of runoff in the Adirondack, White Mountains, and Maine woods area, Bureau of Public Roads

Potter, W. D., 1957b, Peak rates of runoff in the New England Hill and Lowland area, Bureau of Public Roads

Richardson, E.V. and Davis, S.R., 1995, Evaluating scour at bridges: Federal Highway Administration Hydraulic Engineering Circular No. 18, Publication FHWA-IP-90-017, 204 p.

Richardson, E.V., Simons, D.B., and Julien, P.Y., 1990, Highways in the river environment: Federal Highway Administration Publication FHWA-HI-90-016.

Ritter, D.F., 1984, Process Geomorphology: W.C. Brown Co., Debuque, Iowa, 603 p.

Shearman, J.O., 1990, User's manual for WSPRO--a computer model for water surface profile computations: Federal Highway Administration Publication FHWA-IP-89-027, 187 p.

Shearman, J.O., Kirby, W.H., Schneider, V.R., and Flippo, H.N., 1986, Bridge waterways analysis model; research report: Federal Highway Administration Publication FHWA-RD-86-108, 112 p.

Talbot, A.N., 1887, The determination of water-way for bridges and culverts.

U.S. Geological Survey, 1986, Mount Holly, Vermont 7.5 Minute Series quadrangle map: U.S. Geological Survey Topographic Maps, Scale $1: 24,000$.

U.S. Geological Survey, 1986, Wallingford, Vermont 7.5 Minute Series quadrangle map: U.S. Geological Survey Topographic Maps, Scale $1: 24,000$. 


\section{APPENDIX A: \\ WSPRO INPUT FILE}




\section{WSPRO INPUT FILE}

GR

GR

GR

*

$\mathrm{N}$

SA

*

X

*

BR

GR

GR

GR

*

$\mathrm{N}$

*

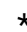

$\mathrm{CD}$

*

*

XR

GR

GR

*

AS

GR

GR

GR

GR

GR

$\mathrm{N}$

SA

*

HP 1 BRIDG 489.601489 .60

HP 2 BRIDG 489.60 * * 2550

HP 1 APPR3 $493.34 \quad 1 \quad 493.34$

HP 2 APPR3 493.34* * 2550

HP 1 BRIDG 491.081491 .08

HP 2 BRIDG 491.08 * * 3500

HP 1 APPR3 495.561495 .56

BRIDG

$0.0,496.93$

$11.4,482.97$

$26.9,481.47$

0.045

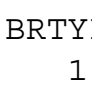

RDWAY

$-41.8,499.99$
0 .

$-60.7,495.43$

$-46.2,494.68$

$0.0,487.43$

$17.6,482.25$

$14.0,482.29$

$48.4,489.37$

$36.2,483.34$

$143.0,509.92$

Date: $05-F E B-98$

$126.6,497.38$

0.060

66.7

0.0

0.050

WWANGL WWWID

45.2 16.3

MBWID IPAVE

.485 .12

$5.5,483.92$

$6.5,483.15$

$20.4,483.62$

$29.5,496.76$

$24.1,483.77$

$0.0,496.93$

$8.7,483.00$

$26.0,482.61$

$66.7,498.45$

$51.3,499.01$
$28.7,499.55$

$110.5,512.31$

0 .

$-108.8,500.51$

$-9.0,498.27$

$14.2,483.73$

$28.4,483.55$

$66.2,496.75$

0.055

56.8

$$
\begin{array}{rr}
-81.9, & 500.14 \\
-6.0, & 492.46 \\
17.6, & 483.70 \\
30.7, & 484.30 \\
74.0, & 499.56
\end{array}
$$

0.070

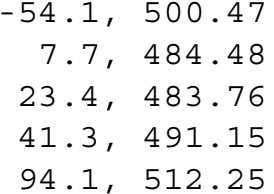




\section{APPENDIX B: \\ WSPRO OUTPUT FILE}


WSPRO OUTPUT FILE

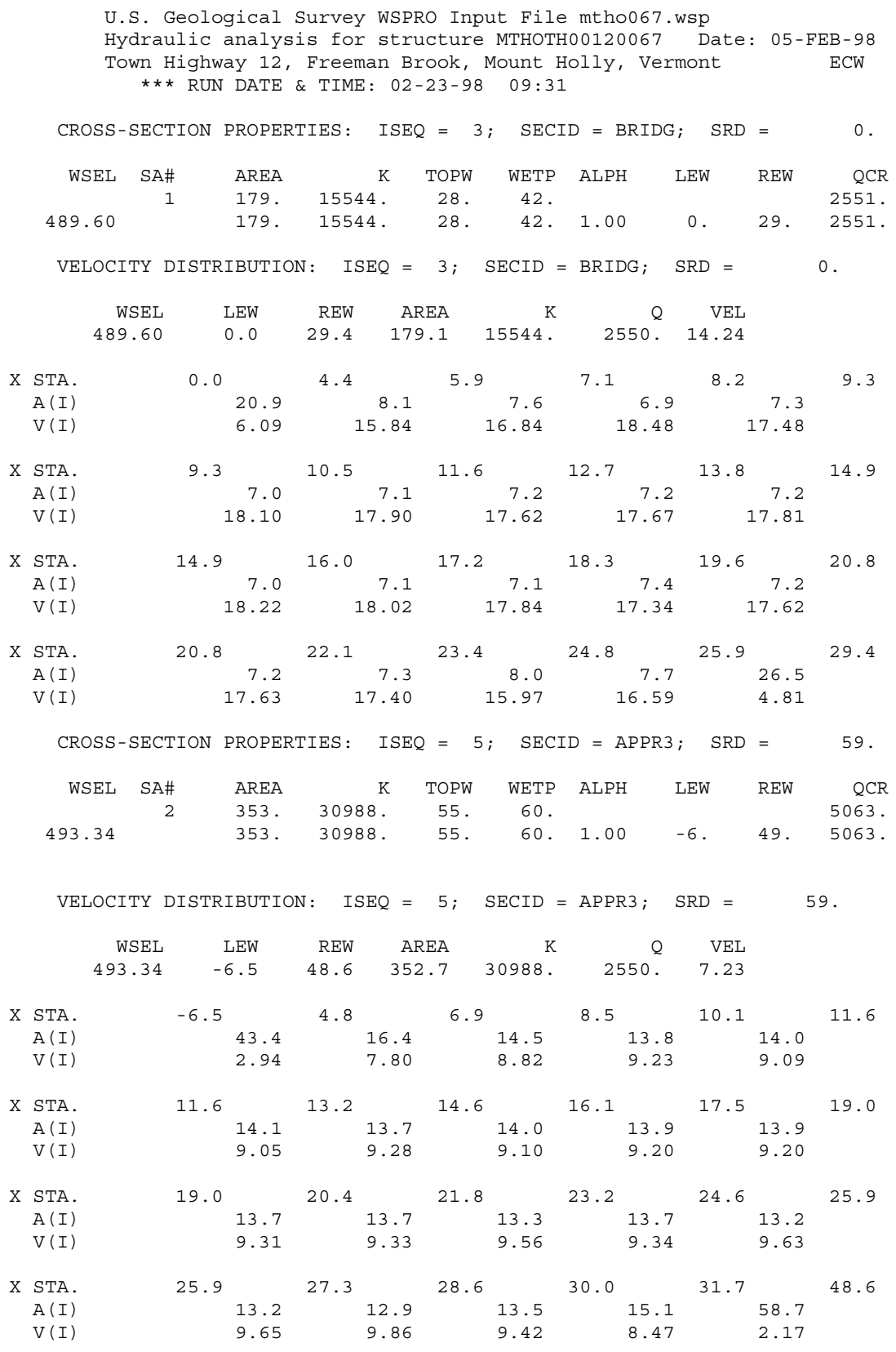


WSPRO OUTPUT FILE (continued)

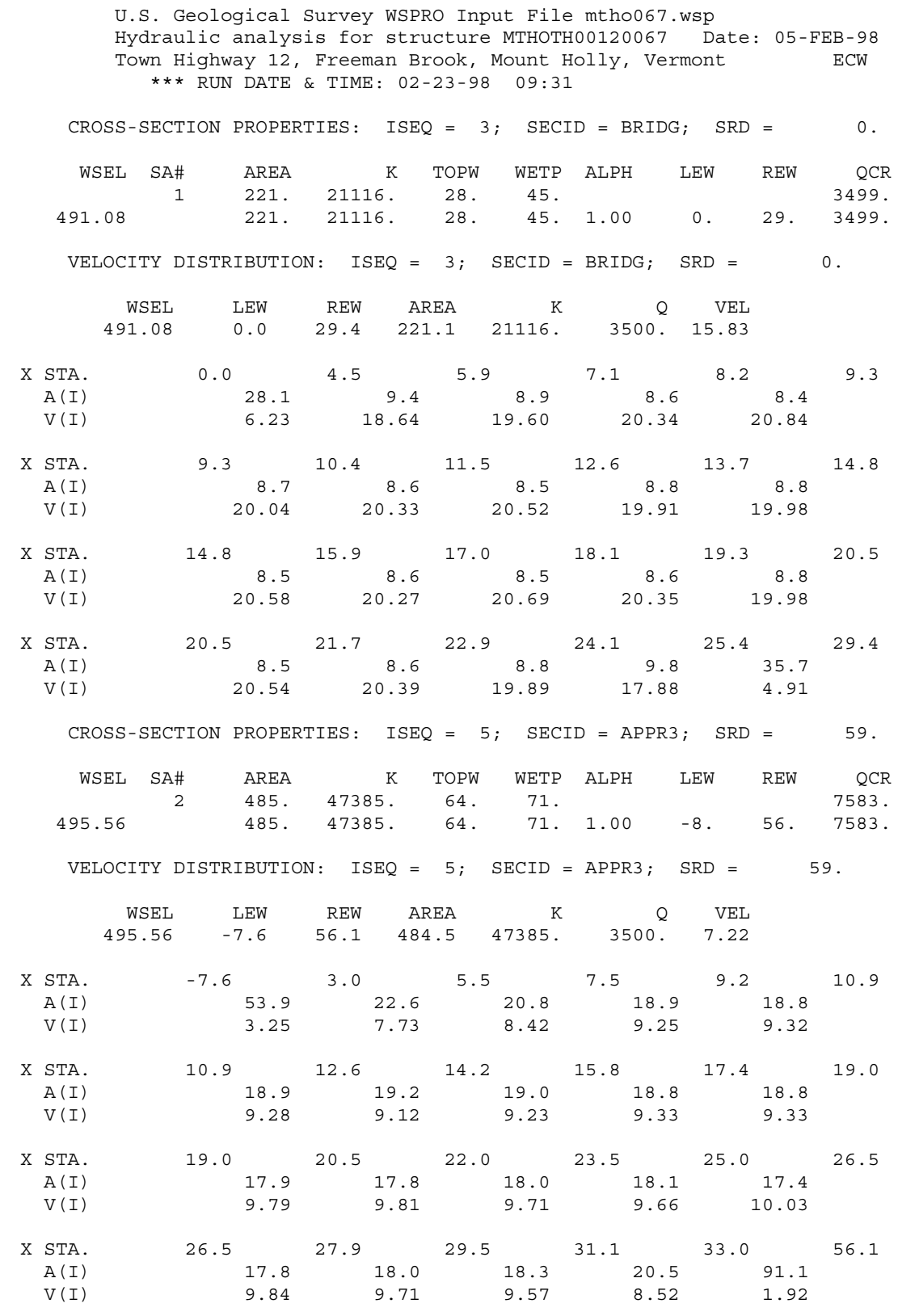


WSPRO OUTPUT FILE (continued)

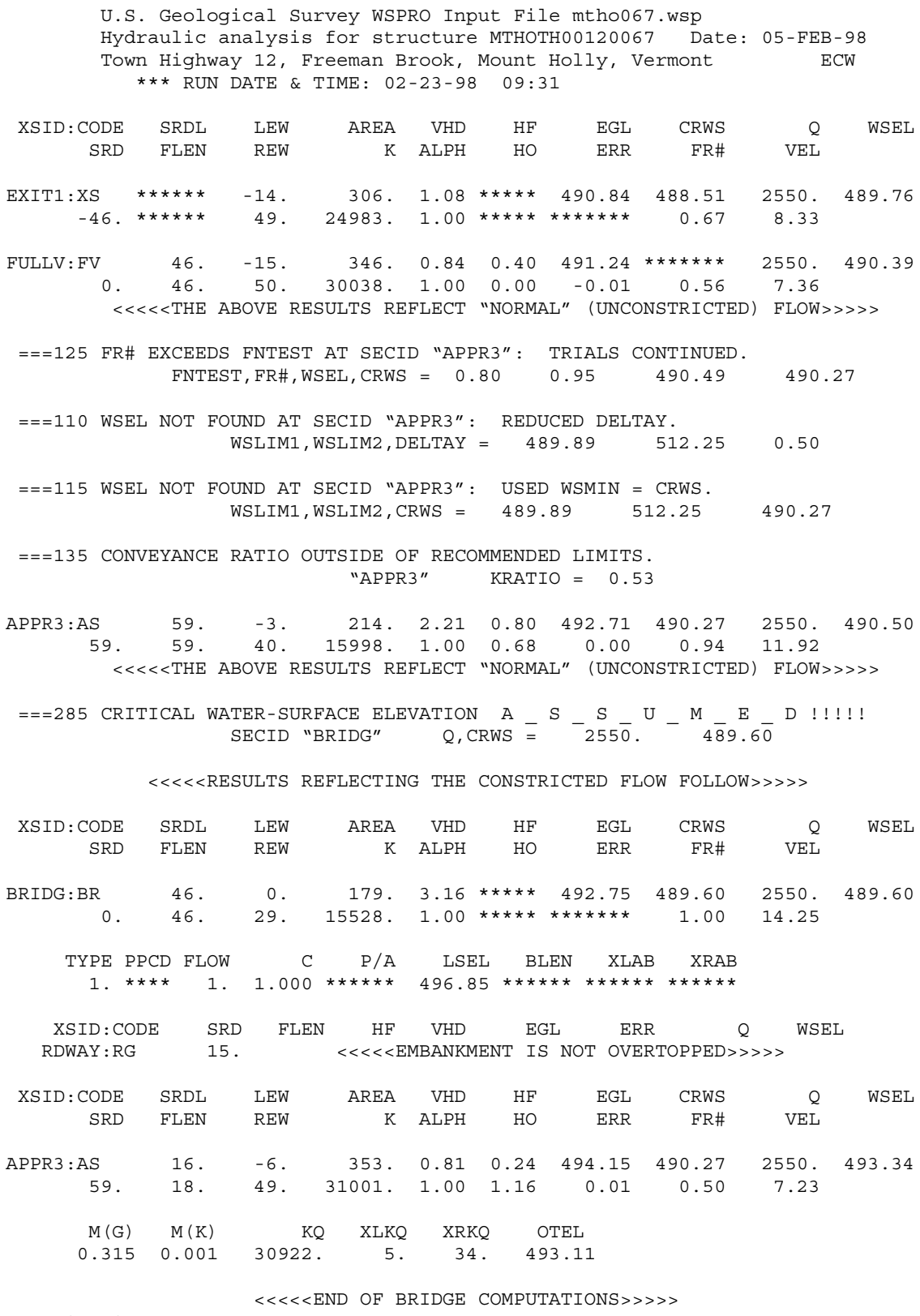


WSPRO OUTPUT FILE (continued)

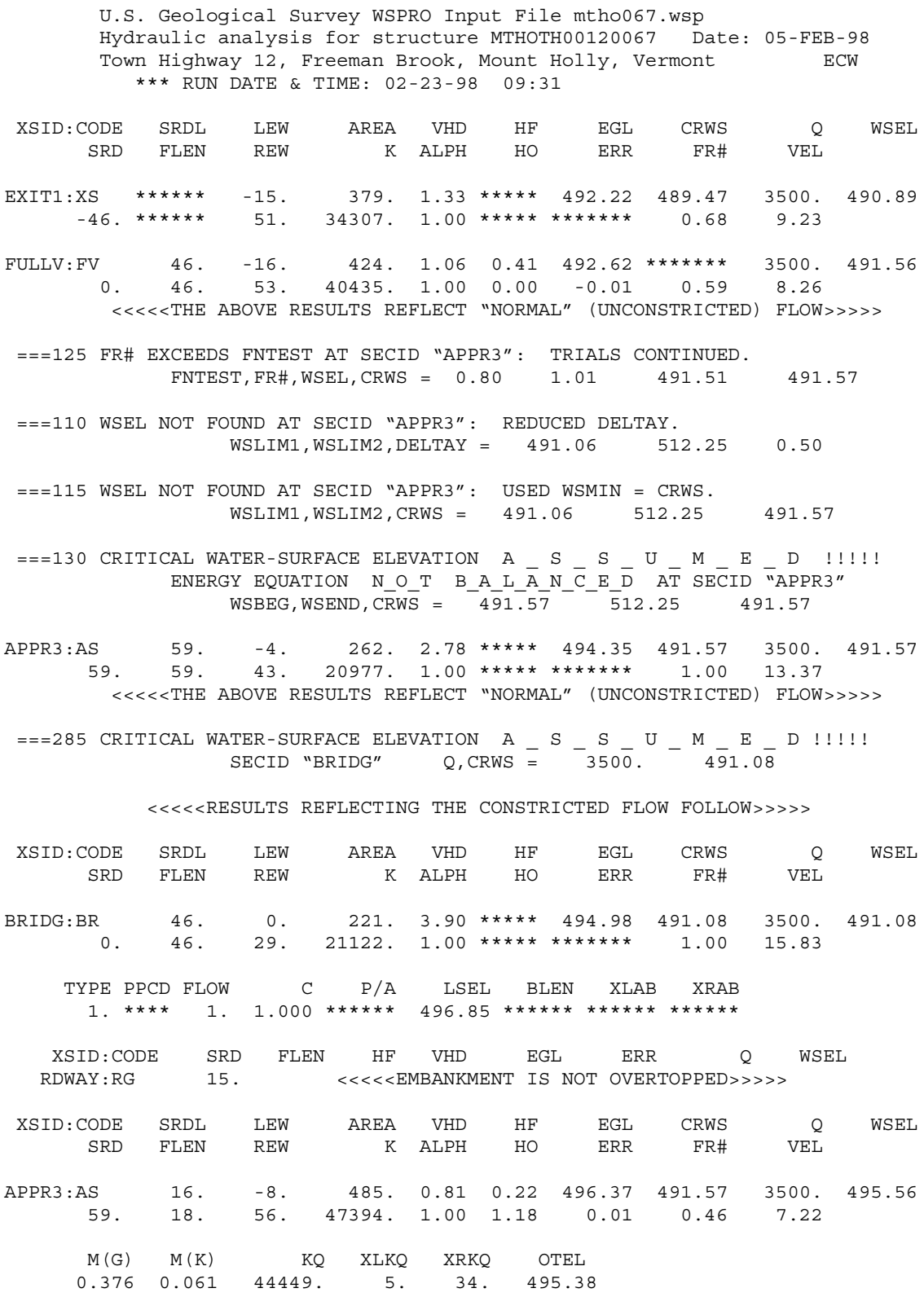




\section{APPENDIX C:}

\section{BED-MATERIAL PARTICLE-SIZE DISTRIBUTION}




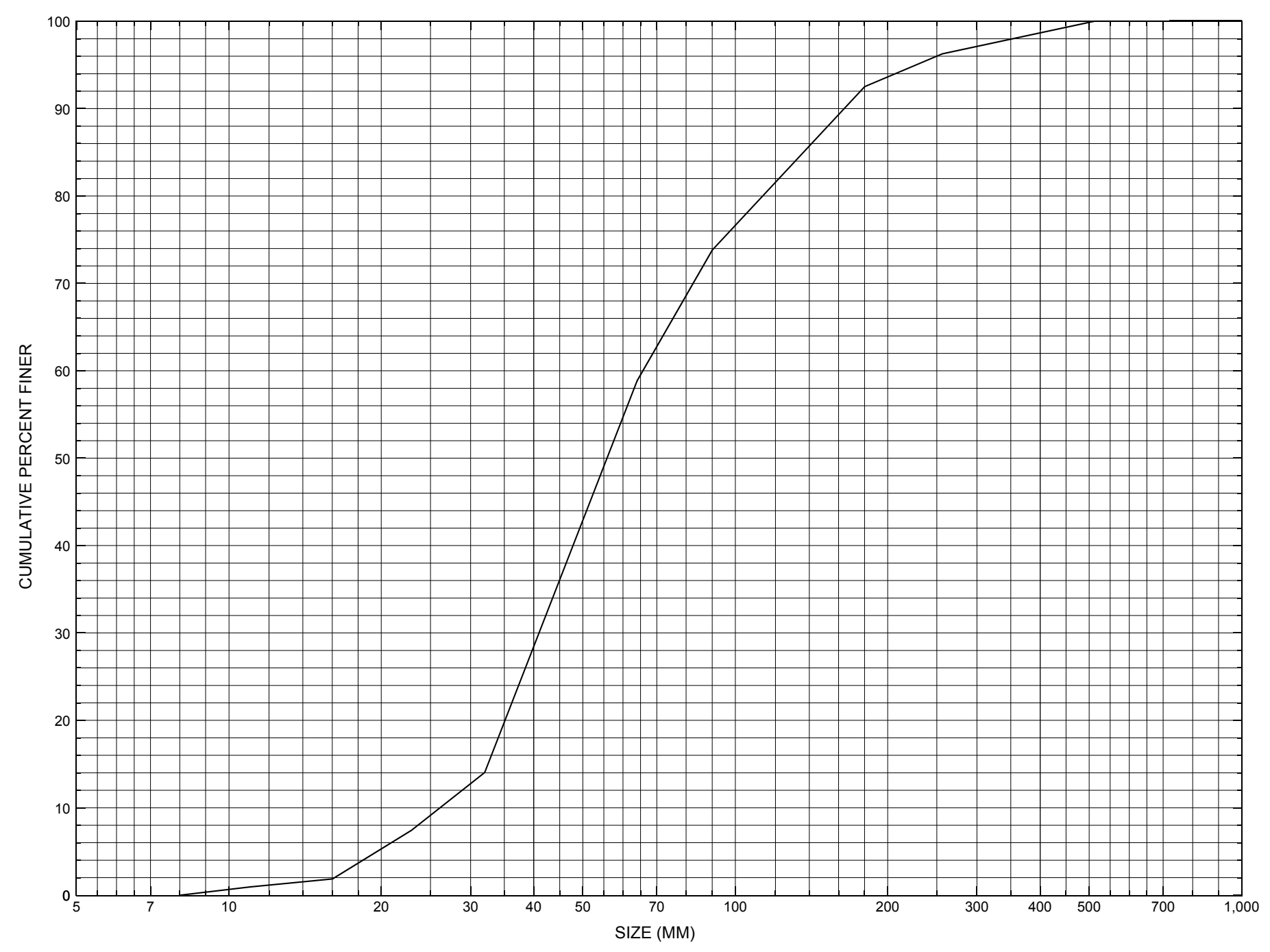

Appendix C. Bed material particle-size distribution for a pebble count in the channel approach of structure MTHOTH00120067, in Mount Holly, Vermont. 


\section{APPENDIX D: \\ HISTORICAL DATA FORM}




\section{Structure Number MTHOTH00120067}

\section{General Location Descriptive}

Data collected by (First Initial, Full last name) $\mathbf{E}$. BOEHMLER

Date $(M M / D D / Y Y) \_\mathbf{0 3} / \underline{15} / \underline{95}$

Highway District Number $(I-2 ; n n) \underline{\mathbf{0 3}}$

Town (FIPS place code; I - 4; nnnnn) $\mathbf{4 7 2 0 0}$

Waterway (I - 6) FREEMAN BROOK

Route Number TH012

Topographic Map Mount Holly

Latitude (I - 16; nnnn.n) $\mathbf{4 3 2 8 6}$
County (FIPS county code; I - 3; nnn)

Mile marker (I - 11; nnn.nnn) $\mathbf{0 0 0 0 0 0}$

Road Name (I - 7): -

Vicinity (I - 9) 0.5 MI TO JCT W VT103

Hydrologic Unit Code: $\underline{\mathbf{0 2 0 1 0 0 0 2}}$

Longitude (i - 17; nnnnn.n) 72519

\section{Select Federal Inventory Codes}

FHWA Structure Number (I - 8) 10111200671112

Maintenance responsibility $(I-21 ; n n) \quad \mathbf{0 3}$

Year built (I - 27; YYYY) 1973

Average daily traffic, ADT (I - 29; nnnnnn) 000150

Year of ADT (I - 30; YY) $\mathbf{9 2}$

Opening skew to Roadway $(I-34 ; n n) \quad 15$

Operational status $(I-41 ; X)$ A

Structure type (I - 43; nnn) $\mathbf{5 0 1}$

Approach span structure type $(I-44 ; n n n) \quad \mathbf{0 0 0}$

Number of spans (I - 45; nnn) $\mathbf{0 0 1}$

Number of approach spans (I - 46; nnnn) $\mathbf{0 0 0 0}$

Comments:

The structural inspection report of 6/8/94 indicates the structure is a prestressed concrete slab type bridge. The abutment walls and wingwalls are concrete on which there are randomly distributed fine cracks. Concrete scaling is reported primarily along the bottom section of the right abutment wall. Local scour is noted along the right abutment and its downstream wingwall, which has an exposed footing. The footing concrete is noted as having heavy scaling but no undermining. Most of the channel flow is along the right abutment. Heavy riprap protection is reported in front of each upstream wingwall and along the left abutment wall. A gravel point bar is reported along the left abutment side of the (Cont., page 31) 


\section{Bridge Hydrologic Data}

Is there hydrologic data available? $\underline{\mathbf{N}}$ if No, type ctrl-n $h \quad$ VTAOT Drainage area $\left(m i^{2}\right): \mathbf{1 1 . 8}$

Terrain character:

Stream character \& type:

Streambed material:

Discharge Data (cfs):

$$
\mathrm{Q}_{2.33} \frac{-}{\mathbf{2 2 0 0}}
$$

$\mathrm{Q}_{10} \frac{\mathbf{1 5 0 0}}{\mathrm{Q}_{100}-}$

$\mathrm{Q}_{25} \lcm{\mathbf{1 8 4 0}}$

$Q_{500}$

Record flood date ( $M M / D D / Y Y$ ):

Water surface elevation (ft): -

Estimated Discharge (cfs): Velocity at $\mathrm{Q} \underline{\mathbf{2 5}}$ $(\mathrm{ft} / \mathrm{s}): \mathbf{1 2 . 5}$

Ice conditions (Heavy, Moderate, Light) : Debris (Heavy, Moderate, Light):

The stage increases to maximum highwater elevation (Rapidly, Not rapidly):

The stream response is (Flashy, Not flashy):

Describe any significant site conditions upstream or downstream that may influence the stream's stage: -

Watershed storage area (in percent):

The watershed storage area is: - _ (1-mainly at the headwaters; 2- uniformly distributed; 3-immediatly upstream oi the site)

Water Surface Elevation Estimates for Existing Structure:

\begin{tabular}{|l|l|l|l|l|l|}
\hline Peak discharge frequency & $Q_{2.33}$ & $Q_{10}$ & $Q_{25}$ & $Q_{50}$ & $Q_{100}$ \\
Water surface elevation (ft) $)$ & - & - & $\mathbf{7 . 8}$ & - & - \\
Velocity $(\mathrm{ft} / \mathrm{sec})$ & - & - & $\mathbf{1 2 . 5}$ & - & - \\
\hline
\end{tabular}

Long term stream bed changes: -

Is the roadway overtopped below the $\mathrm{Q}_{100}$ ? (Yes, No, Unknown): $\mathbf{U} \quad$ Frequency: Relief Elevation $(f t)$ : Discharge over roadway at $Q_{100}\left(f t^{3} / \mathrm{sec}\right)$ :

Are there other structures nearby? (Yes, No, Unknown): $\mathbf{U}$ Upstream distance (miles): Town: If No or Unknown, type ctrl-n os Highway No. : Structure No. : Year Built:

Clear span (ft): Clear Height (ft): Full Waterway $\left(f t^{2}\right)$ : 
Downstream distance (miles): Town: Year Built:

Highway No. : Structure No. : Structure Type:

Clear span $(f t):$ Clear Height $(f t)$ : Full Waterway $\left(f^{2}\right)$ :

Comments:

channel. The channel is noted as lined with stone and boulders upstream and downstream, which may provide some protection. There is very limited hydrologic data provided on an office memorandum in the hydraulics section files.

\section{USGS Watershed Data}

Watershed Hydrographic Data

Drainage area $(D A) \underline{11.38} \mathrm{mi}^{2}$ Lake/pond/swamp area 0.02 $\mathrm{mi}^{2}$

Watershed storage (ST) $\%$

Bridge site elevation 1161 $\mathrm{ft}$ Headwater elevation 3286 $\mathrm{ft}$

Main channel length $\mathbf{5 . 3 3}$ mi

$10 \%$ channel length elevation 1181 $\mathrm{ft} \quad 85 \%$ channel length elevation 2000 $\mathrm{ft}$

Main channel slope (S)

Watershed Precipitation Data

Average site precipitation in Average headwater precipitation in

Maximum 2yr-24hr precipitation event $(124,2)$ in

Average seasonal snowfall (Sn) $\mathrm{ft}$ 


\section{Bridge Plan Data}

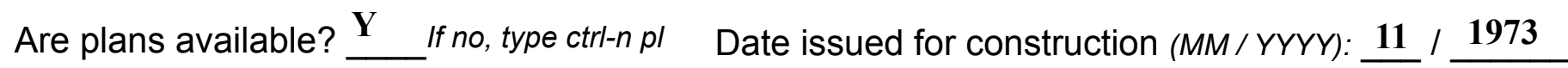
Project Number STF-9437

Minimum channel bed elevation: $\mathbf{5 0 5 . 0}$

Low superstructure elevation: USLAB $\underline{\mathbf{5 1 8 . 2 6}}$ DSLAB $\underline{\mathbf{5 1 9 . 2 1}}$ USRAB $\mathbf{5 1 7 . 9 9}$ DSRAB $\underline{\mathbf{5 1 8 . 9 4}}$ Benchmark location description:

BM\#2, a spike [in root or trunk of] a 24 in hemlock tree between a 6 in ash and 12 in poplar tree on the temporary stretch of roadway on the right bank upstream that once led to a temporary bridge. The tree is about 50 feet from the right bank of the stream and 20 feet from the centerline of the temporary roadway right bankward, elevation 518.49.

Reference Point (MSL, Arbitrary, Other): Arbitrary _ Datum (NAD27, NAD83, Other): Arbitrary Foundation Type: 1 (1-Spreadfooting; 2-Pile; 3- Gravity; 4-Unknown)

If 1: Footing Thickness $\mathbf{2 . 0} \quad$ Footing bottom elevation: $\underline{\mathbf{5 0 1 . 0}}$

If 2: Pile Type: __ (1-Wood; 2-Steel or metal; 3-Concrete) Approximate pile driven length:

If 3: Footing bottom elevation:

Is boring information available? $\mathbf{N}$ If no, type ctrl- $n$ bi Number of borings taken: _-

Foundation Material Type: $\mathbf{3}$ (1-regolith, 2-bedrock, 3-unknown)

Briefly describe material at foundation bottom elevation or around piles:

$-$

Comments:

These plans are listed under the last project number which is STF 9437. The same hydraulic data on the bridge given in the previous section are printed on the plans. Additional reference marks that may be used are: 1) the point on the top streamward edge of the upstream right wingwall, where the slope of the concrete changes from horizontal to downward, elevation shown is 519.95; and 2) another point in the same location as in, but on the upstream left wingwall and the elevation shown is 520.22 . 


\section{Cross-sectional Data}

Is cross-sectional data available? $\underline{\mathbf{Y}}$

If no, type ctrl-n xs

Source (FEMA, VTAOT, Other)? VTAOT

Some cross sections of the stream were generated and kept with the plans, which may be Comments: retrieved when needed. No reproducible bridge cross sections.

\begin{tabular}{|l|l|l|l|l|l|l|l|l|l|l|l|}
\hline Station & - & - & - & - & - & - & - & - & - & - & - \\
\hline Feature & - & - & - & - & - & - & - & - & - & - & - \\
\hline $\begin{array}{l}\text { Low chord } \\
\text { elevation }\end{array}$ & - & - & - & - & - & - & - & - & - & - & - \\
\hline $\begin{array}{l}\text { Bed } \\
\text { elevation }\end{array}$ & - & - & - & - & - & - & - & - & - & - & - \\
\hline $\begin{array}{l}\text { Low chord } \\
\text { to bed }\end{array}$ & - & - & - & - & - & - & - & - & - & - & - \\
\hline Station & - & - & - & - & - & - & - & - & - & - & - \\
\hline Feature & - & - & - & - & - & - & - & - & - & - & - \\
\hline $\begin{array}{l}\text { Low chord } \\
\text { elevation }\end{array}$ & - & - & - & - & - & - & - & - & - & - & - \\
\hline $\begin{array}{l}\text { Bed } \\
\text { elevation }\end{array}$ & - & - & - & - & - & - & - & - & - & - & - \\
\hline $\begin{array}{l}\text { Low chord } \\
\text { to bed }\end{array}$ & - & - & - & - & - & - & - & - & - & - & - \\
\hline
\end{tabular}

Source (FEMA, VTAOT, Other)?

Comments: -

\begin{tabular}{|l|l|l|l|l|l|l|l|l|l|l|l|}
\hline Station & - & - & - & - & - & - & - & - & - & - & - \\
\hline Feature & - & - & - & - & - & - & - & - & - & - & - \\
\hline $\begin{array}{l}\text { Low chord } \\
\text { elevation }\end{array}$ & - & - & - & - & - & - & - & - & - & - & - \\
\hline $\begin{array}{l}\text { Bed } \\
\text { elevation }\end{array}$ & - & - & - & - & - & - & - & - & - & - & - \\
\hline $\begin{array}{l}\text { Low chord } \\
\text { to bed }\end{array}$ & - & - & - & - & - & - & - & - & - & - & - \\
\hline Station & - & - & - & - & - & - & - & - & - & - & - \\
\hline Feature & - & - & - & - & - & - & - & - & - & - & - \\
\hline $\begin{array}{l}\text { Low chord } \\
\text { elevation }\end{array}$ & - & - & - & - & - & - & - & - & - & - & - \\
\hline $\begin{array}{l}\text { Bed } \\
\text { elevation }\end{array}$ & - & - & - & - & - & - & - & - & - & - & - \\
\hline $\begin{array}{l}\text { Low chord } \\
\text { to bed }\end{array}$ & - & - & - & - & - & - & - & - & - & - & - \\
\hline
\end{tabular}




\section{APPENDIX E: \\ LEVEL I DATA FORM}


U. S. Geological Survey

Bridge Field Data Collection and Processing Form

Qa/Qc Check by: CG Date: 2/09/96

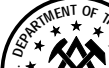

\section{Structure Number МТНОТН00120067}

Computerized by: $\mathrm{CG}$ Date: $2 / \mathbf{1 2 / 9 6}$

Reviewd by: $\quad$ EW Date: $\underline{2 / 25 / 98}$

\section{A. General Location Descriptive}

1. Data collected by (First Initial, Full last name) $\underline{\mathbf{T}}$. Severance

Date $(M M / D D / Y Y) \underline{10} / \underline{\mathbf{0 5}} / \underline{1995}$

2. Highway District Number $\mathbf{0 3}$

County Rutland (021)

Mile marker -

Waterway $(I-6)$ Freeman Brook

Town Mount Holly (47200)

Route Number TH 012

Road Name Freeman Brook Road

3. Descriptive comments:

Hydrologic Unit Code: $\mathbf{0 2 0 1 0 0 0 2}$

The bridge is located 0.5 miles to junction with VT 103.

\section{B. Bridge Deck Observations}
4. Surface cover... LBUS 6
RBUS 6
LBDS 6
RBDS 6
Overall 6

(2b us,ds,lb,rb: 1- Urban; 2- Suburban; 3- Row crops; 4- Pasture; 5- Shrub- and brushland; 6- Forest; 7- Wetland)

5. Ambient water surface... US $\underline{\mathbf{2}}$ UB $\underline{\mathbf{2 , 1}}$ DS $\underline{\mathbf{2 , 1}}$ (1-pool; 2-riffle)

6. Bridge structure type 1 (1- single span; 2- multiple span; 3- single arch; 4- multiple arch; 5-cylindrical culvert; 6- box culvert; or 7- other)
7. Bridge length $\mathbf{3 4}$
(feet)
Span length $\mathbf{3 0}$
(feet)
Bridge width 25.2 (feet)

\section{Road approach to bridge:}
8. LB 2 RB 1
( 0 even, 1- lower, 2- higher)
9. LB 2
RB $\underline{2}$
(1-Paved, 2- Not paved)

10. Embankment slope (run / rise in feet / foot)
US left
2.1:1
US right
2.6:1

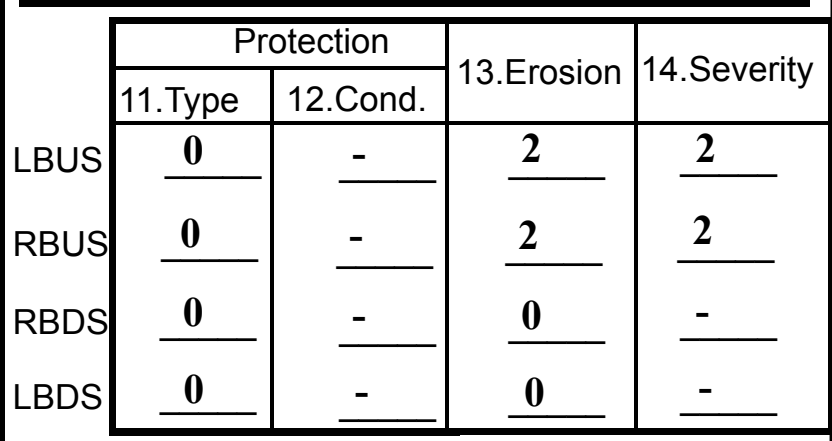

Bank protection types: 0- none; 1- $<12$ inches;

2- $<36$ inches; $3-<48$ inches;

4- < 60 inches; 5- wall / artificial levee

Bank protection conditions: 1- good; 2- slumped;

3- eroded; 4- failed

Erosion: 0 - none; 1- channel erosion; 2 -

road wash; 3- both; 4- other

Erosion Severity: 0 - none; 1- slight; 2- moderate; 3- severe

\section{Channel approach to bridge (BF):}

15. Angle of approach: 0

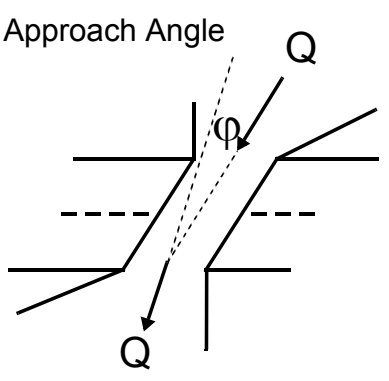

17. Channel impact zone 1 :

Where? RB (LB, RB)

Range? 5 feet US

Channel impact zone 2:

Where? LB $(L B, R B)$

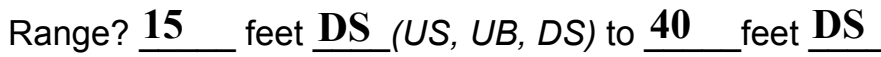

Impact Severity: 0- none to very slight; 1-Slight; 2- Moderate; 3- Severe

16. Bridge skew: $\mathbf{5 0}$ Bridge Skew Angle

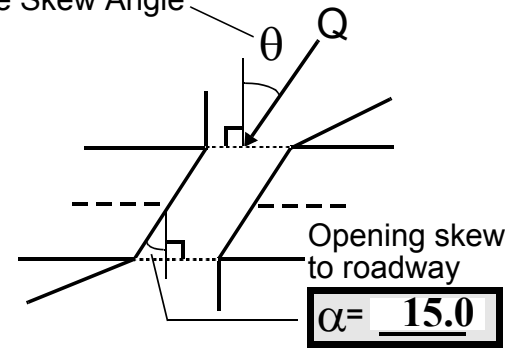

\section{Exist? $\mathbf{Y}(Y$ or $N)$}

Severity 2

, UB, DS) to 28 feet $\underline{\mathbf{U B}}$

Exist? $\mathbf{Y}(Y$ or $N)$

Severity 1

o roadway 
18. Bridge Type: 4

1a- Vertical abutments with wingwalls

$1 \mathrm{~b}$ - Vertical abutments without wingwalls

2- Vertical abutments and wingwalls, sloping embankment Wingwalls parallel to abut. face

3- Spill through abutments

4- Sloping embankment, vertical wingwalls and abutments

Wingwall angle less than $90^{\circ}$.

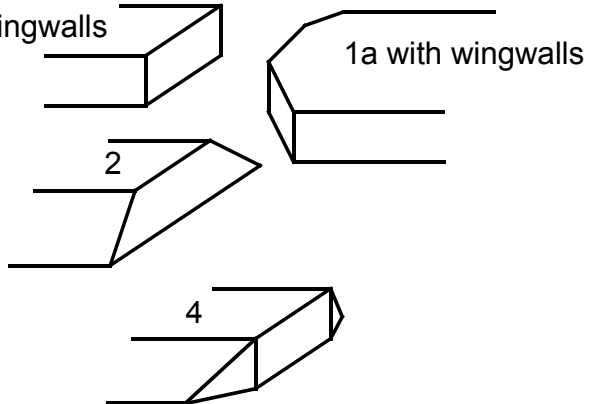

19. Bridge Deck Comments (surface cover variations, measured bridge and span lengths, bridge type variations, approach overflow width, etc.)

7: Values are from the VTAOT database. The measured bridge length equals $34 \mathrm{ft}$, span length equals $32 \mathrm{ft}$, clear span equals $30 \mathrm{ft}$, and bridge width equals $24.6 \mathrm{ft}$.

The clear span was measured from abutment edge to abutment edge.

Guard rails are along the upstream and downstream bridge deck and out onto the road approach.

The stream is in a V-notch valley.

8. The right road approach is slightly higher near the bridge than the left road approach. Then, the right road approach is lower than the bridge.

\section{Upstream Channel Assessment}

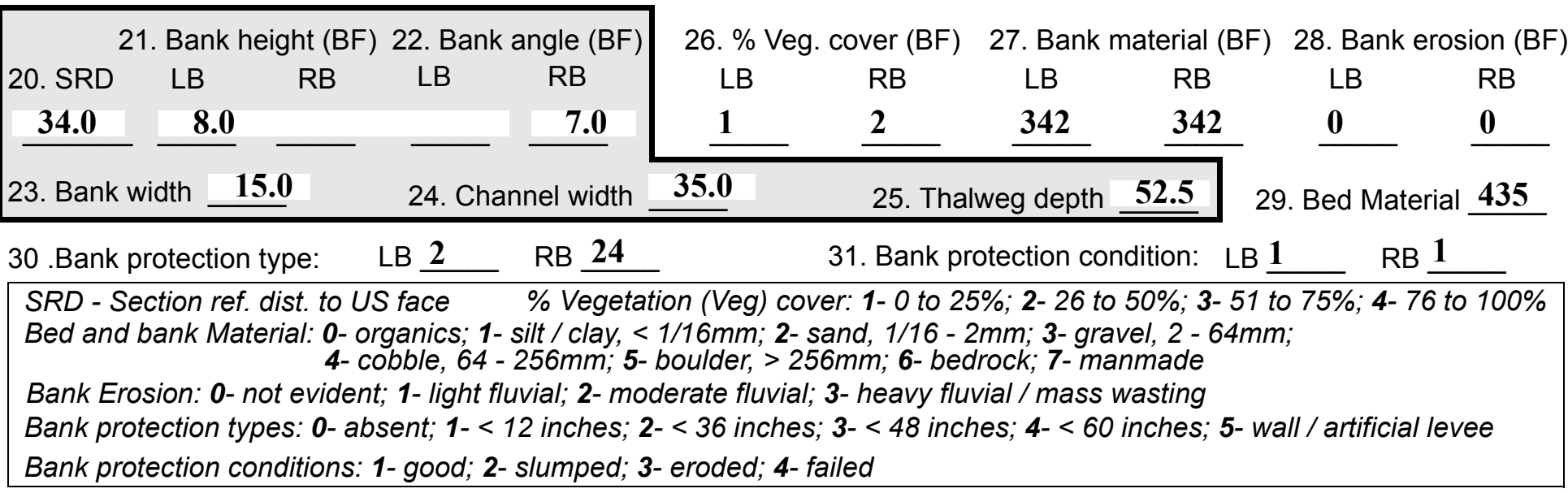

32. Comments (bank material variation, minor inflows, protection extent, etc.):

Both upstream banks are protected with boulders.

The roadway runs along/close to the left bank. Therefore the bank is made up of roadbed material consisting of cobbles, gravel and boulders.

The protection along the right bank extends upstream 114 feet. The protection from the bridge to 60 feet upsteam is type-2 and from 60 feet to 114 feet upstream is type-4. 

feet $\underline{\mathbf{U S}}$

(US, UB, DS) positioned $\mathbf{0}$ $\%$ LB to 60 $\%$ RB

37. Material: $\mathbf{4 3 5}$

38. Point or side bar comments (Circle Point or Side; Note additional bars, material variation, status, etc.):

This is a point bar. The boulders have probably fallen or rolled from the upstream left bank protection.

There are bars upstream along the locally braided reach (142 feet upstream to 300 feet upstream).

39. Is a cut-bank present? $\mathbf{Y}$ (Y or if $N$ type ctrl-n cb)

40. Where? $\underline{\mathbf{L B}}$ (LB or RB)

41. Mid-bank distance: 191

42. Cut bank extent: 135 feet $\underline{\mathbf{U S}}$

(US, UB) to $\underline{\mathbf{3 0 0}}$ feet $\underline{\mathrm{US}}$ (US, UB, DS)

43. Bank damage: 2

(1- eroded and/or creep; 2- slip failure; 3- block failure)

44. Cut bank comments (eg. additional cut banks, protection condition, etc.):

The cut bank starts where the left bank protection ends. It is opposite the center of the area where the channel is braided and has bars.

\section{Is channel scour present? $\mathbf{Y}$ ( $Y$ or if $N$ type ctrl-n cs) $\quad$ 46. Mid-scour distance: $\mathbf{3 9}$}
47. Scour dimensions: Length 15
Width 4
Depth : 1.2
Position 65
$\%$ LB to $\underline{80}$
$\%$ RB

48. Scour comments (eg. additional scour areas, local scouring process, etc.):

There is some localized scouring in pools. The stream is riffled at the locally braided area upstream.

\section{Are there major confluences? $\mathbf{N}$}

51. Confluence 1: Distance -

Confluence 2: Distance -

54. Confluence comments (eg. confluence name):

NO MAJOR CONFLUENCES
(Y or if $N$ type ctrl-n mc)

52. Enters on (LB or $R B)$

Enters on (LB or $R B)$
50. How many? -

53. Type( 1- perennial; 2- ephemeral)

Type (1-perennial; 2-ephemeral)

\section{Under Bridge Channel Assessment}

55. Channel restraint (BF)? LB 2

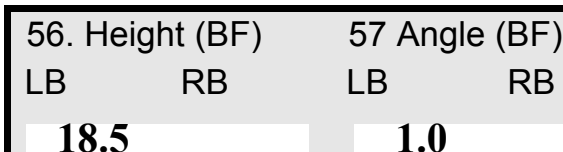

58. Bank width (BF) (1- natural bank; 2- abutment; 3- artificial levee)

Bed and bank Material: 0- organics; 1- silt / clay, < 1/16mm; 2- sand, 1/16 - 2mm; 3- gravel, 2 - 64mm; 4- cobble, 64 - 256mm; 5- boulder, > 256mm; 6- bedrock; 7- manmade

\begin{tabular}{llll} 
61. Material (BF) & \multicolumn{2}{l}{ 62. Erosion (BF) } \\
LB & RB & LB & RB \\
$\mathbf{2}$ & - & & - \\
\hline
\end{tabular}

60. Thalweg depth $\mathbf{9 0 . 0}$

63. Bed Material -

Bank Erosion: 0- not evident; 1- light fluvial; 2- moderate fluvial; 3- heavy fluvial / mass wasting

64. Comments (bank material variation, minor inflows, protection extent, etc.):

42

There is a point bar, 6 feet under the bridge to 45 feet under the bridge. The downstream end is sand and the upstream end is cobble, with gravel mixed over the entire bar. The mid-bar distance is at 20 feet under bridge. The mid-bar width is 16 feet. The channel takes up the entire width between the two abutments at the upstream bridge face. Flow is then directed at the right abutment from 5 feet to 20 feet under the bridge, across the upstream end of the under bridge point bar.

63. Bed material is cobbles with sand along the base of the right abutment. 
65. Debris and Ice Is there debris accumulation?

(Yor $N)$ 66. Where? $\underline{Y}$

(1- Upstream; 2- At bridge; 3- Both)

67. Debris Potential 1 ( 1- Low; 2- Moderate; 3- High)

68. Capture Efficiency 2

(1-Low; 2- Moderate; 3- High)

69. Is there evidence of ice build-up? 1 ( $Y$ or $N)$

Ice Blockage Potential $\mathbf{N}$

(1- Low; 2- Moderate; 3- High)

70. Debris and Ice Comments:

1

The channel narrows at the bridge, but the clear span is high. The distance between the top of the footing and the low chord is $\mathbf{1 6}$ feet at the downstream end of the right abutment.

\begin{tabular}{|l|c|c|c|c|c|c|c|c|}
\hline Abutments & $\begin{array}{c}\text { 71. Attack } \\
\angle \text { (BF) }\end{array}$ & $\begin{array}{c}\text { 72. Slope } \angle \\
\text { (Qmax) }\end{array}$ & $\begin{array}{c}\text { 73. Toe } \\
\text { loc. (BF) }\end{array}$ & $\begin{array}{c}\text { 74. Scour } \\
\text { Condition }\end{array}$ & $\begin{array}{c}75 . \text { Scour } \\
\text { depth }\end{array}$ & $\begin{array}{c}\text { 76. Exposure } \\
\text { depth }\end{array}$ & 77. Material & 78. Length \\
\hline LABUT & & $\mathbf{0}$ & $\mathbf{9 0}$ & $\mathbf{2}$ & $\mathbf{0}$ & - & - & $\mathbf{9 0 . 0}$ \\
\hline RABUT & $\mathbf{1}$ & $\mathbf{3 0}$ & $\mathbf{9 0}$ & & & $\mathbf{2}$ & $\mathbf{2}$ & $\mathbf{2 8 . 5}$ \\
\hline
\end{tabular}

Pushed: $L B$ or RB

Toe Location (Loc.): 0- even, 1- set back, 2- protrudes

Scour cond.: 0- not evident; 1- evident (comment); 2- footing exposed; 3-undermined footing; 4- piling exposed; 5- settled; 6- failed

Materials: 1- Concrete; 2- Stone masonry or drywall; 3- steel or metal; 4- wood

79. Abutment comments (eg. undermined penetration, unusual scour processes, debris, etc.):

1.1

0.1

1

Just the downstream end of the right abutment has exposure depth, but the top of the footing is exposed for the entire abutment length.

80. Wingwalls:

Exist? Material? Scour Scour Exposure 81. Condition? depth? depth?

USLWW:

28.5

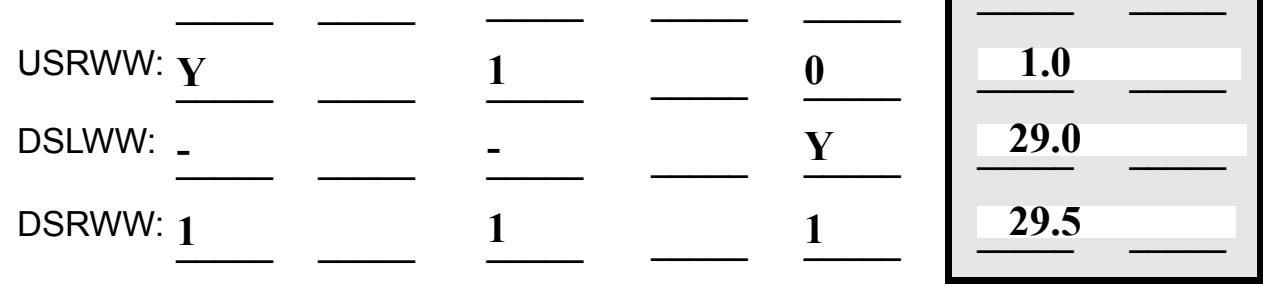

Wingwall materials: 1- Concrete; 2- Stone masonry or drywall; 3- steel or metal; 4- wood

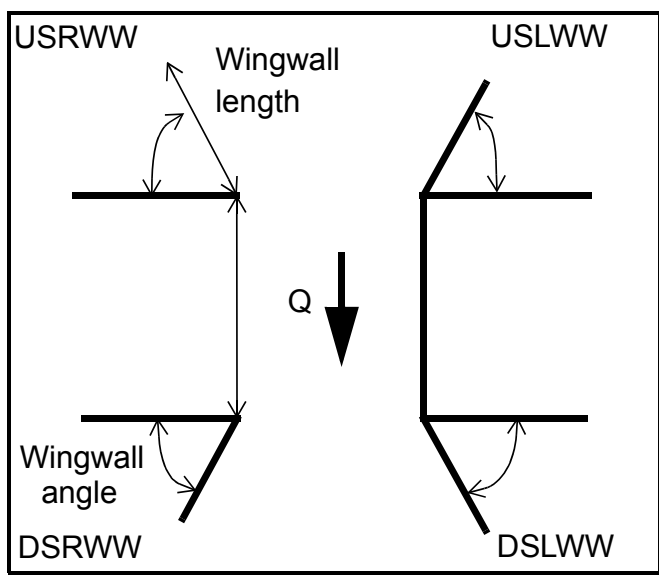

82. Bank / Bridge Protection:

\begin{tabular}{|l|l|l|l|l|l|l|l|c|}
\hline Location & USLWW & USRWW & LABUT & RABUT & LB & RB & DSLWW & DSRWW \\
\hline Type & - & $\mathbf{0}$ & $\mathbf{Y}$ & $\mathbf{2}$ & $\mathbf{1}$ & $\mathbf{1}$ & $\mathbf{1}$ & - \\
\hline Condition & $\mathbf{Y}$ & - & $\mathbf{1}$ & $\mathbf{0 . 3}$ & $\mathbf{1}$ & $\mathbf{1}$ & $\mathbf{1}$ & - \\
\hline Extent & $\mathbf{1}$ & - & $\mathbf{2}$ & $\mathbf{2}$ & $\mathbf{3 , 4}$ & $\mathbf{2}$ & $\mathbf{0}$ & - \\
\hline
\end{tabular}

Bank / Bridge protection types: 0- absent; 1-<12 inches; 2- < 36 inches; 3- < 48 inches; 4- < 60 inches; 
83. Wingwall and protection comments (eg. undermined penetration, unusual scour processes, etc.):

-
-
-
-
-
2
1
1
1
2
3

\section{Piers:}

84. Are there piers? DS (Y or if $N$ type ctrl-n pr)

\begin{tabular}{|l|l|l|l|l|l|l|l|}
\hline \multirow{2}{*}{$\begin{array}{l}85 . \\
\text { Pier no. }\end{array}$} & \multicolumn{3}{|c|}{ width (w) feet } & \multicolumn{3}{c|}{ elevation (e) feet } \\
\cline { 2 - 8 } & w1 & w2 & w3 & e@w1 & e@w2 & e@w3 \\
\hline Pier 1 & & & & $\mathbf{3 0 . 0}$ & $\mathbf{3 0 . 0}$ & $\mathbf{6 0 . 0}$ \\
\hline Pier 2 & & & & $\mathbf{1 4 . 0}$ & $\mathbf{6 0 . 0}$ & $\mathbf{1 1 . 0}$ \\
\hline Pier 3 & & & - & $\mathbf{3 0 . 0}$ & $\mathbf{2 5 . 0}$ & - \\
\hline Pier 4 & - & - & - & - & - & - \\
Nyyyy
\end{tabular}

\begin{tabular}{|l|l|l|l|l|}
\hline Level 1 Pier Descr. & \multicolumn{1}{|c|}{1} & \multicolumn{1}{|c|}{2} & \multicolumn{1}{|c|}{3} & \multicolumn{1}{|c|}{ 86. Location (BF) } \\
\hline 87. Type & RWW- & WW- & DSLW & most \\
\hline 88. Material & The & The & W- & of \\
\hline 89. Shape & upst & foot- & Ther & whic \\
\hline 90. Inclined? & ream & ing is & e is & h is \\
\hline 91. Attack $\angle$ (BF) & end & not & pro- & alon \\
\hline 92. Pushed & the & expo & tec- & g the \\
\hline 93. Length (feet) & - & - & tion & dow \\
\hline 94. \# of piles & foot- & but & alon & nstre \\
\hline 95. Cross-members & ing is & there & g the & am \\
\hline 96. Scour Condition & expo & is & entir & end. \\
\hline 97. Scour depth & sed. & scou & e & DSR \\
\hline 98. Exposure depth & USR & r. & base, & WW \\
\hline
\end{tabular}

LFP, LTB, LB, MCL, MCM, MCR, RB, RTB, RFP

1- Solid pier, 2- column, 3- bent

1-Wood; 2-concrete; 3- metal; 4- stone

1- Round; 2- Square; 3- Pointed

Y-yes; $N-$ no

$L B$ or $R B$

0- none; 1- laterals; 2- diagonals; 3- both

0- not evident; 1- evident (comment);

2- footing exposed; 3- piling exposed;

4- undermined footing; 5- settled; 6- failed 
99. Pier comments (eg. undermined penetration, protection and protection extent, unusual scour processes, etc.):

- There is some small protection at the downstream end. This may be slumped bank protection. The upstream end of the footing is exposed 3 feet. There is some coarse sand at the base of the center of the wingwall.

$\mathbf{N}$

$-$

100.

\section{E. Downstream Channel Assessment}

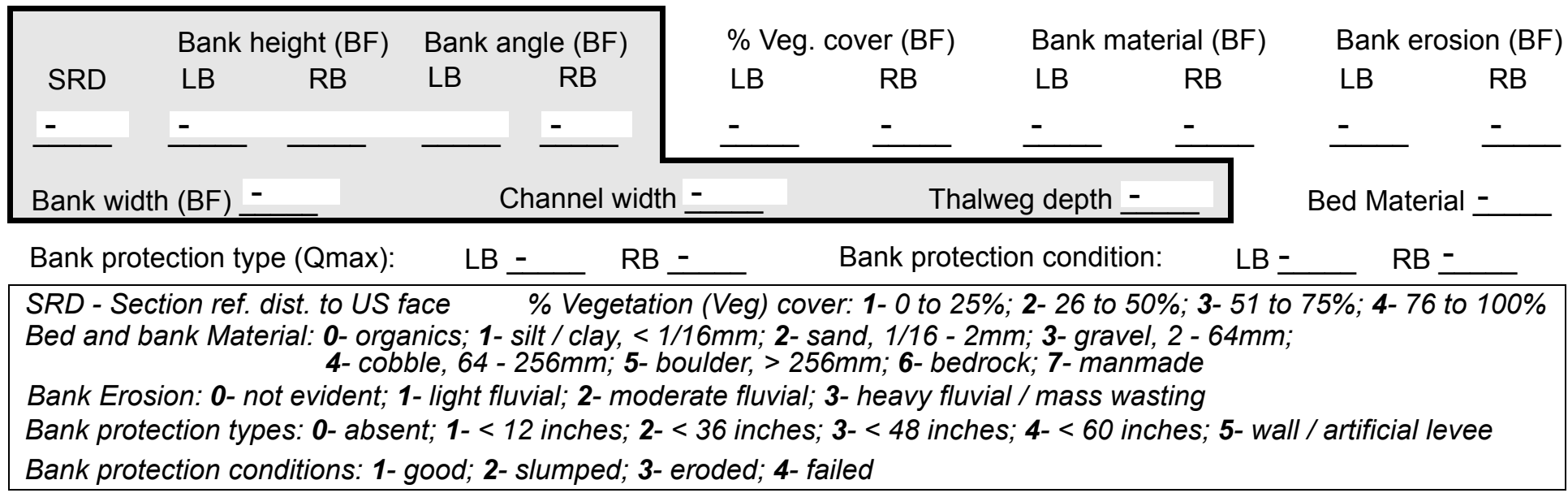

Comments (eg. bank material variation, minor inflows, protection extent, etc.):

$-$

$-$

$-$

$-$

$-$

$-$

$-$

$-$

$-$

$-$

$-$

-

-

-

101. Is a drop structure present? _ ( $Y$ or $N$, if $N$ type ctrl-n ds) 102. Distance: __ feet
103. Drop: - feet
104. Structure material: -
(1- steel sheet pile; 2- wood pile; 3- concrete; 4- other)

105. Drop structure comments (eg. downstream scour depth):

-

-

-

- 
106. Point/Side bar present? (Y or N. if $N$ type ctrl-n pb)Mid-bar distance: -

Mid-bar width: -

Point bar extent: feet -

(US, UB, DS) to feet (US, UB, DS) positioned $\%$ LB to $\% \mathrm{RB}$

Material:

Point or side bar comments (Circle Point or Side; note additional bars, material variation, status, etc.):

$-$

$-$

NO PIERS

Is a cut-bank present? (Y or if $N$ type ctrl-n cb) Where? (LB or $R B$ )

Mid-bank distance:

Cut bank extent: feet (US, UB, DS) to feet (US, UB, DS)

Bank damage: (1- eroded and/or creep; 2- slip failure; 3- block failure)

Cut bank comments (eg. additional cut banks, protection condition, etc.):

\section{3 \\ 2}

34

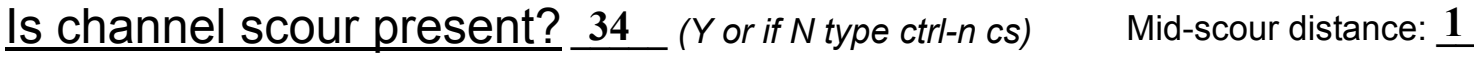
Scour dimensions: Length $\underline{1}$ Width $\underline{4}$ Depth: $\underline{3} \quad$ Positioned $\underline{3}$ \%LB to $\underline{1}$ \%RB Scour comments (eg. additional scour areas, local scouring process, etc.): 1

Bank material is cobble and gravel. The fines have been washed out in places.

There is stone protection along both downstream banks. The left bank protection extends from the downstream left wingwall to 41 feet downstream. The right bank protection extends from the downstream end of Are there major confluences? th (Y or if $N$ type ctrl-n $m c) \quad$ How many?

Confluence 1: Distance down Enters on stre $(L B$ or $R B)$

Type am (1- perennial; 2- ephemeral)

Confluence 2: Distance right Enters on win $(L B$ or $R B)$

Type gwa (1-perennial; 2- ephemeral)

Confluence comments (eg. confluence name):

Il to 80 feet downstream.

There is a bedrock outcrop 220 feet to 265 feet downstream on the left bank. A portion of this outcrop sticks

\section{F. Geomorphic Channel Assessment}

$\begin{array}{ll}\text { 107. Stage of reach evolution out } & \text { 1- Constructed } \\ \text { 2- Stable } & \text { 3-Aggraded } \\ \text { 4- Degraded } & \text { 5- Laterally unstable } \\ & \mathbf{6} \text { - Vertically and laterally unstable }\end{array}$


108. Evolution comments (Channel evolution not considering bridge effects; See HEC-20, Figure 1 for geomorphic descriptors):

into the channel.

There are cutbanks along both downstream banks.

There is some scattered debris.

$\mathbf{N}$

-

NO DROP STRUCTURE 


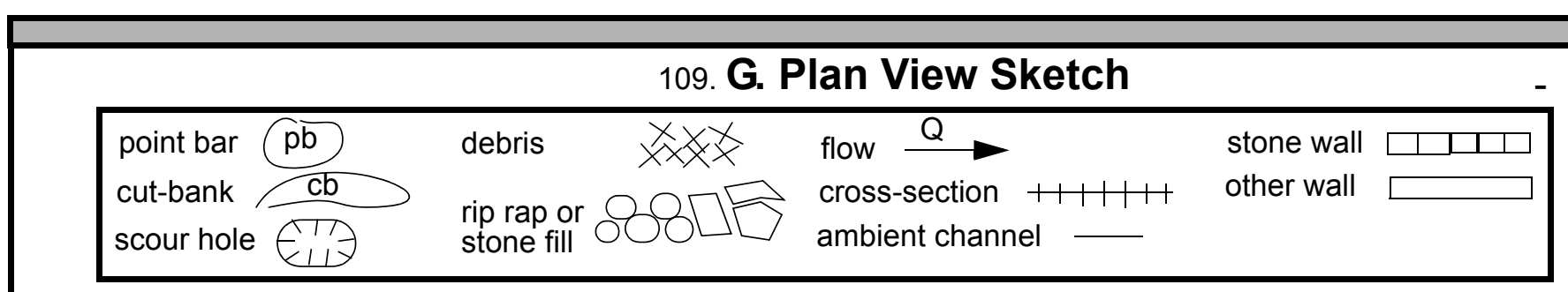


APPENDIX F:

SCOUR COMPUTATIONS 


\begin{tabular}{|c|c|c|c|}
\hline Structure Number: MTHOTH00120067 & & Town: & MOUNT HOLLY \\
\hline Road Number: $\quad$ TH 12 & & County: & RUTLAND \\
\hline Stream: FREEMAN BROOK & & & \\
\hline Initials ECW & Checked: & LKS & \\
\hline alysis of contraction scour, liv & d or $c$ & ear wa & \\
\hline $\begin{array}{l}\text { Critical Velocity of Bed Material } \\
\text { VC=11.21*y1^0.1667*D50^0.33 with S } \\
\text { (Richardson and Davis, 1995, p. } 28\end{array}$ & $\begin{array}{l}\text { Converted } \\
=2.65 \\
\text { eq. } 16)\end{array}$ & to Eng & sh units) \\
\hline Approach Section & & & \\
\hline Characteristic & $100 \mathrm{yr}$ & $500 \mathrm{yr}$ & other $Q$ \\
\hline Total discharge, cfs & 2550 & 3500 & 0 \\
\hline Main Channel Area, ft2 & 353 & 485 & 0 \\
\hline Left overbank area, ft2 & 0 & 0 & 0 \\
\hline Right overbank area, ft2 & 0 & 0 & 0 \\
\hline Top width main channel, ft & 55 & 64 & 0 \\
\hline Top width L overbank, ft & 0 & 0 & 0 \\
\hline Top width $\mathrm{R}$ overbank, ft & 0 & 0 & 0 \\
\hline D50 of channel, ft & 0.183 & 0.183 & 0.183 \\
\hline D50 left overbank, ft & -- & -- & -- \\
\hline D50 right overbank, ft & -- & -- & -- \\
\hline Y1, average depth, MC, ft & 6.4 & 7.6 & ERR \\
\hline Y1, average depth, LOB, ft & $\mathrm{ERR}$ & ERR & ERR \\
\hline Y1, average depth, ROB, ft & ERR & ERR & $\mathrm{ERR}$ \\
\hline Total conveyance, approach & 30988 & 47385 & 0 \\
\hline Conveyance, main channel & 30988 & 47385 & 0 \\
\hline Conveyance, LOB & 0 & 0 & 0 \\
\hline Conveyance, ROB & 0 & 0 & 0 \\
\hline Percent discrepancy, conveyance & 0.0000 & 0.0000 & $\mathrm{ERR}$ \\
\hline Qm, discharge, MC, cfs & 2550.0 & 3500.0 & ERR \\
\hline Q1, discharge, LOB, Cfs & 0.0 & 0.0 & ERR \\
\hline Qr, discharge, ROB, cfs & 0.0 & 0.0 & $\mathrm{ERR}$ \\
\hline Vm, mean velocity $\mathrm{MC}$, ft/s & 7.2 & 7.2 & ERR \\
\hline VI, mean velocity, LOB, ft/s & ERR & ERR & ERR \\
\hline Vr, mean velocity, ROB, ft/s & $\mathrm{ERR}$ & $\mathrm{ERR}$ & ERR \\
\hline Vc-m, crit. velocity, $M C$, ft/s & 8.7 & 8.9 & $\mathrm{~N} / \mathrm{A}$ \\
\hline Vc-l, crit. velocity, LOB, ft/s & ERR & ERR & ERR \\
\hline Vc-r, crit. velocity, ROB, ft/s & $\mathrm{ERR}$ & $\mathrm{ERR}$ & ERR \\
\hline Results & & & \\
\hline Live-bed(1) or Clear-Water(0) Cont & action Sc & bur? & \\
\hline Main Channel & 0 & 0 & $\mathrm{~N} / \mathrm{A}$ \\
\hline Left Overbank & $\mathrm{N} / \mathrm{A}$ & $\mathrm{N} / \mathrm{A}$ & $\mathrm{N} / \mathrm{A}$ \\
\hline Right Overbank & $\mathrm{N} / \mathrm{A}$ & $\mathrm{N} / \mathrm{A}$ & $\mathrm{N} / \mathrm{A}$ \\
\hline
\end{tabular}


Clear water Contraction Scour in MAIN CHANNEL

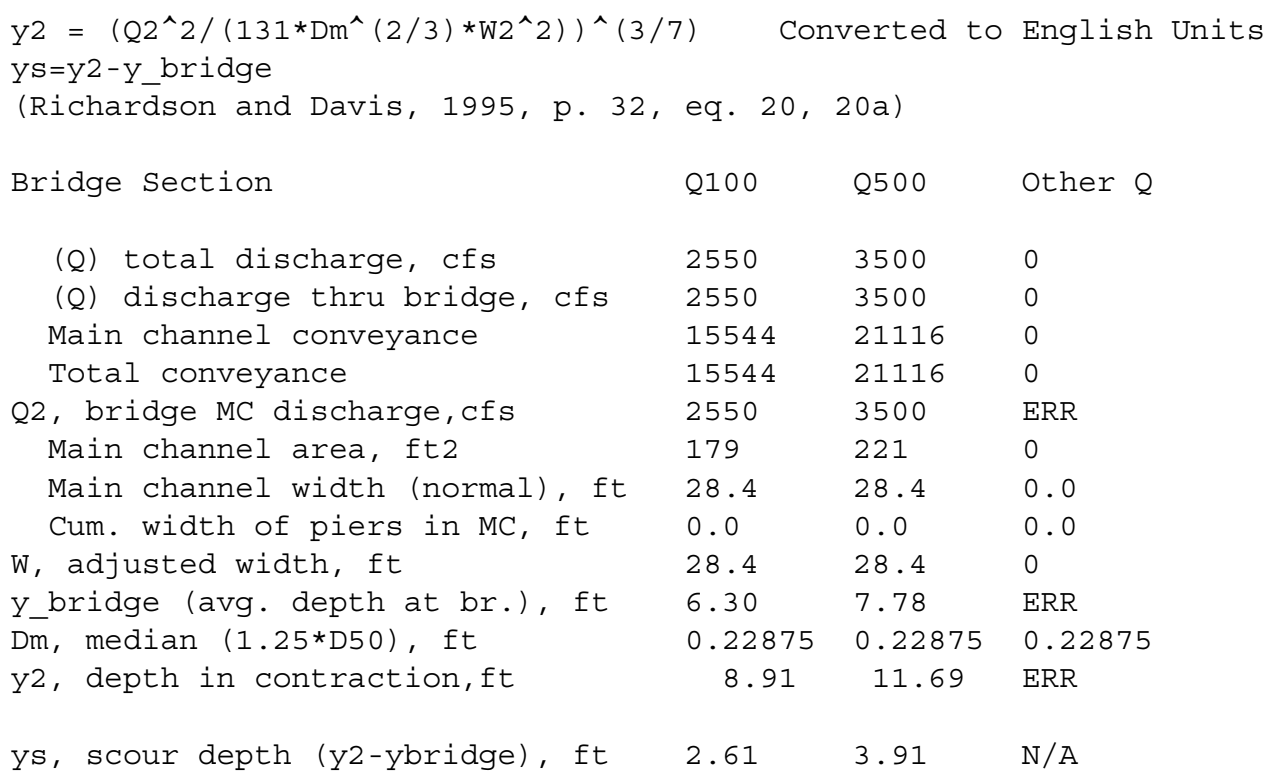


Abutment Scour

Froehlich's Abutment Scour

$\mathrm{Ys} / \mathrm{Y} 1=2.27 * \mathrm{~K} 1 * \mathrm{~K} 2 *\left(\mathrm{a}^{\prime} / \mathrm{Y} 1\right) \wedge 0.43 * \mathrm{Fr} 1 \wedge 0.61+1$

(Richardson and Davis, 1995, p. 48, eq. 28)

\begin{tabular}{|c|c|c|c|c|c|c|}
\hline \multirow[b]{2}{*}{ Characteristic } & \multicolumn{2}{|c|}{ Left Abutment } & \multicolumn{4}{|c|}{ Right Abutment } \\
\hline & \multicolumn{3}{|c|}{100 yr Q 500 yr Q Other } & \multicolumn{3}{|c|}{$100 \mathrm{yr} Q 500 \mathrm{yr} Q$ Other Q } \\
\hline (Qt), total discharge, cfs & 2550 & 3500 & 0 & 2550 & 3500 & 0 \\
\hline a', abut.length blocking flow, ft & 7 & 8.1 & 0 & 19.7 & 27.2 & 0 \\
\hline Ae, area of blocked flow ft 2 & 26.88 & 41.19 & 0 & 84.41 & 136.65 & 0 \\
\hline Qe, discharge blocked abut., cfs & 78.98 & 133.73 & 0 & 355.18 & 590.63 & 0 \\
\hline \multicolumn{7}{|c|}{ (If using Qtotal_overbank to obtain Ve, leave Qe blank and enter Ve and Fr manually) } \\
\hline Ve, $(\mathrm{Qe} / \mathrm{Ae}), \mathrm{ft} / \mathrm{s}$ & 2.94 & 3.25 & ERR & 4.21 & 4.32 & ERR \\
\hline ya, depth of $\mathrm{f} / \mathrm{p}$ flow, ft & 3.84 & 5.09 & ERR & 4.28 & 5.02 & ERR \\
\hline --Coeff., K1, for abut. type (1.0, & \multicolumn{6}{|c|}{ verti.; 0.82, verti. w/ wingwall; 0.55, spillthru) } \\
\hline & 0.82 & 0.82 & 0.82 & 0.82 & 0.82 & 0.82 \\
\hline --Angle (theta) of embankment $(<90$ & \multicolumn{6}{|c|}{ points DS; >90 if abut. points US) } \\
\hline theta & 75 & 75 & 75 & 105 & 105 & 105 \\
\hline K2 & 0.98 & 0.98 & 0.98 & 1.02 & 1.02 & 1.02 \\
\hline Fr, froude number $f / p$ flow & 0.264 & 0.254 & ERR & 0.358 & 0.340 & ERR \\
\hline ys, scour depth, ft & 7.85 & 9.98 & $\mathrm{~N} / \mathrm{A}$ & 12.67 & 15.23 & $\mathrm{~N} / \mathrm{A}$ \\
\hline \multicolumn{7}{|l|}{ HIRE equation (a'/ya > 25) } \\
\hline \multicolumn{7}{|c|}{$\mathrm{YS}=4 * \mathrm{Fr}^{\wedge} 0.33 * \mathrm{y} 1 * \mathrm{~K} / 0.55$} \\
\hline$a^{\prime}$ (abut length blocked, ft) & 7 & 8.1 & 0 & 19.7 & 27.2 & 0 \\
\hline y1 (depth f/p flow, ft) & 3.84 & 5.09 & ERR & 4.28 & 5.02 & ERR \\
\hline$a^{\prime} / y^{1}$ & 1.82 & 1.59 & ERR & 4.60 & 5.41 & ERR \\
\hline Skew correction (p. 49, fig. 16) & 0.95 & 0.95 & 0.95 & 1.03 & 1.03 & 1.03 \\
\hline Froude no. f/p flow & 0.26 & 0.25 & $\mathrm{~N} / \mathrm{A}$ & 0.36 & 0.34 & $\mathrm{~N} / \mathrm{A}$ \\
\hline Ys w/ corr. factor K1/0.55: & & FRR & FR & FRR & FRR & FRR \\
\hline vertical w/ ww's & ERR & $\mathrm{ERR}$ & ERR & $\mathrm{ERR}$ & ERR & $\mathrm{ERR}$ \\
\hline spill-through & ERR & ERR & ERR & ERR & ERR & ERR \\
\hline
\end{tabular}




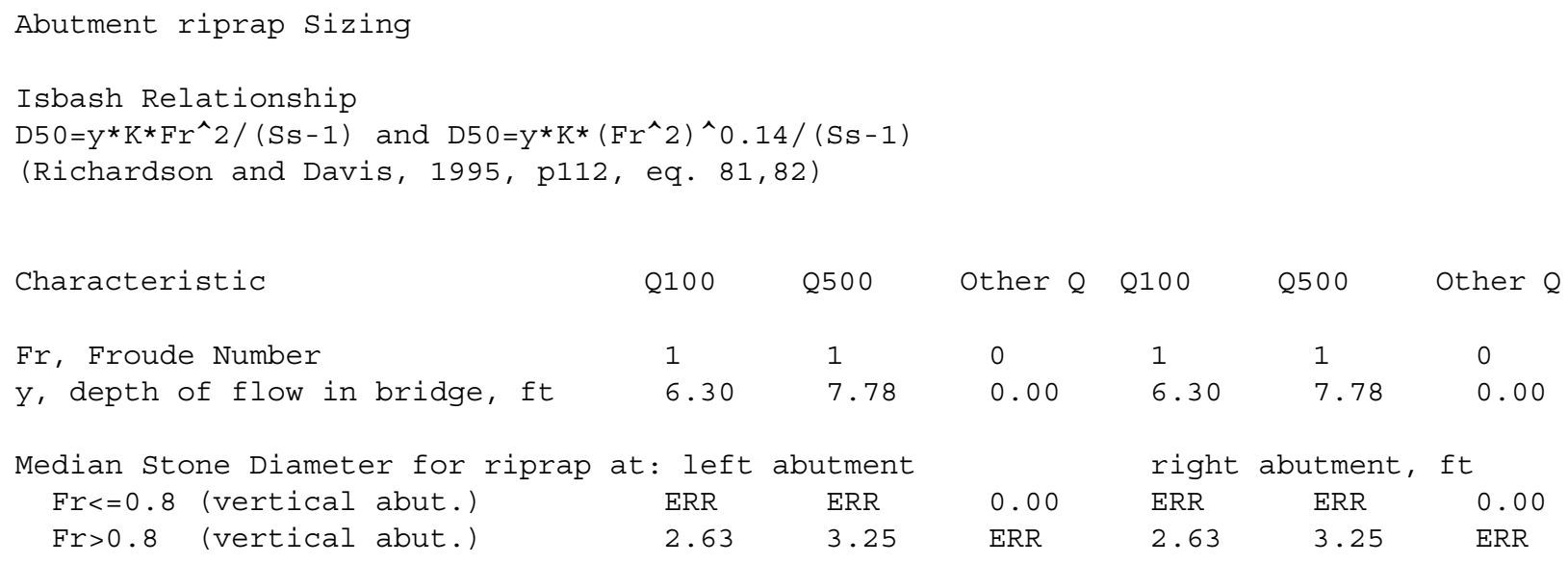

